\title{
Nitrogen effect on carbon-water coupling in forests, grasslands, and shrublands in the arid western United States
}

\author{
Benjamin S. Felzer, ${ }^{1}$ Timothy W. Cronin, ${ }^{2}$ Jerry M. Melillo, ${ }^{3}$ David W. Kicklighter, ${ }^{3}$ \\ C. Adam Schlosser, ${ }^{2}$ and Shree R. S. Dangal ${ }^{1}$ \\ Received 29 November 2010; revised 11 May 2011; accepted 26 May 2011; published 25 August 2011.
}

[1] As greenhouse gases, including $\mathrm{CO}_{2}$, accumulate in the atmosphere, the western United States is predicted to undergo large-scale climate warming and reduced summer precipitation in the coming decades. In this study we explore the role of these climate changes with elevated $\mathrm{CO}_{2}$ to determine the plant physiological response on primary productivity and associated feedbacks on evapotranspiration (ET) and runoff using a biogeochemistry model, TEM-Hydro, with downscaled climate data for the western United States from the NCAR CCSM3 A2 scenario. Net primary productivity increases by $32 \%$ in forests due to feedbacks between warmer temperatures and enhanced nitrogen mineralization but decreases in shrublands by $24 \%$ due to excessive drying and reduced nitrogen mineralization. Warming directly increases nitrogen mineralization rates but indirectly decreases them by reducing soil moisture, so the net effect is highly dependent on climatic conditions within each biome. Increased soil moisture resulting from larger water use efficiency from the elevated $\mathrm{CO}_{2}$ leads to more net nitrogen mineralization in forests, which reduces $\mathrm{N}$-limiting conditions. The effect of $\mathrm{CO}_{2}$ on stomatal conductance is therefore enhanced because of its effect on reducing nitrogen limiting conditions. Runoff decreases over the 21 st century by $22 \%$ in forests, $58 \%$ in grasslands, and $67 \%$ in shrublands due to the reduced precipitation in each region but is modulated by the plant-induced changes in ET. The role of moisture limitation is therefore a crucial regulator of nitrogen limitation, which determines the future productivity and water availability in the West.

Citation: Felzer, B. S., T. W. Cronin, J. M. Melillo, D. W. Kicklighter, C. A. Schlosser, and S. R. S. Dangal (2011), Nitrogen effect on carbon-water coupling in forests, grasslands, and shrublands in the arid western United States, J. Geophys. Res., 116, G03023, doi:10.1029/2010JG001621.

\section{Introduction}

[2] Vegetation in the western United States is ultimately moisture-limited due to the arid environment. Limited water supply results in vast areas of shrubland, grassland, and deserts. Forest growth and regrowth are dependent upon fires resulting from droughts [Running, 2006; Westerling et al., 2006]. Productivity and mortality in western forests depend upon available soil moisture and drought conditions [Hanson and Weltzin, 2000; van Mantgem et al., 2009]. Streamflow in shrublands or grasslands is close to zero much of the time [Wilcox et al., 2006]. The west is currently undergoing an extended drought since the late 1990s [Cook et al., 2004; Piechota et al., 2004]. This region is subject to

\footnotetext{
${ }^{1}$ Earth and Environmental Sciences Department, Lehigh University, Bethlehem, Pennsylvania, USA.

${ }^{2}$ MIT Joint Program on the Science and Policy of Global Change Massachusetts, Institute of Technology, Cambridge, Massachusetts, USA.

${ }^{3}$ Ecosystems Center, Marine Biological Laboratory, Woods Hole, Massachusetts, USA.

Copyright 2011 by the American Geophysical Union. 0148-0227/11/2010JG001621
}

potentially devastating effects from future warming, which could contribute to even more extended droughts.

[3] Soil moisture is dependent upon supply and demand. The supply includes precipitation and spring snowmelt from the mountains. The demand is evapotranspiration, including plant transpiration, soil evaporation, and evaporation of water collected in the canopy. Climate warming will increase demand by increasing evapotranspiration, as will higher photosynthetic rates and increased leaf area index (LAI). Most models also predict a reduction in supply in the West resulting from reduced precipitation, as well as less soil moisture during the growing season due to earlier spring snowmelt [Intergovernmental Panel on Climate Change (IPCC), 2007; Seager et al., 2007; Sheffield and Wood, 2008]. Excess water either goes into surface runoff or groundwater, which may eventually both end up in streamflow that can be measured by gauges. The U.S. Geological Survey (USGS) network of streamflow gauges provides a comprehensive data set of streamflow in western basins.

[4] Transpiration, in turn, is dependent upon solar radiation and vapor pressure deficit and is regulated by plant 


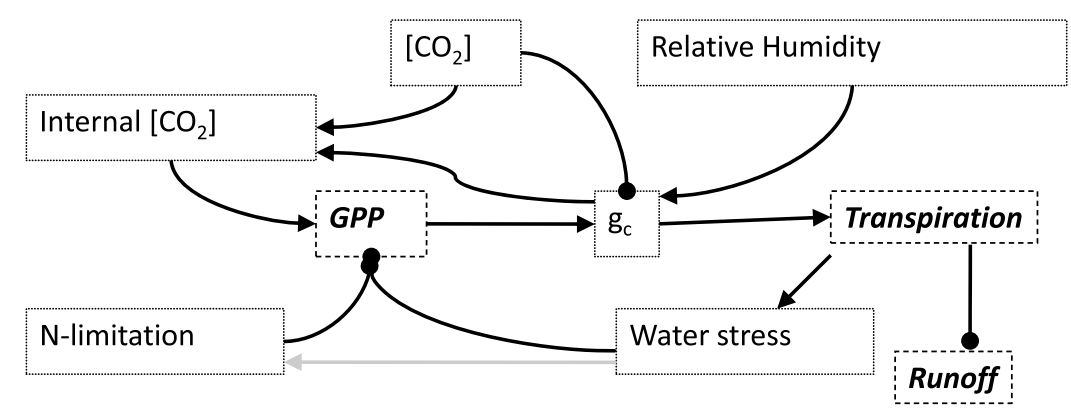

Figure 1. Carbon-nitrogen-water coupling in TEM-Hydro. Arrows indicate positive feedback couplings, and circles indicate negative feedback couplings. The gray arrow represents a new coupling that is emphasized in these experiments. Dashed boxes are fluxes. GPP, gross primary productivity; gc, canopy conductance; $\left[\mathrm{CO}_{2}\right]$, atmospheric concentration of carbon dioxide; internal $\left[\mathrm{CO}_{2}\right]$, concentration of carbon dioxide within plant tissue.

stomata [Federer et al., 1996]. More radiation or drier air increases evapotranspiration rates. Stomatal conductance increases with more photosynthesis and higher relative humidity but decreases with elevated $\mathrm{CO}_{2}$. Photosynthetic rates are highly restricted by either moisture or nutrient limitations but otherwise are dependent upon temperature, moisture, radiation, atmospheric $\mathrm{CO}_{2}$, [Raich et al., 1991] and pollutants such as ozone [Felzer et al., 2007]. Plants generally respond positively to warmer temperatures up to a certain optimal temperature and positively to increased moisture, radiation and atmospheric $\mathrm{CO}_{2}$, while ozone restricts photosynthetic rates. The complexity of these feedbacks is illustrated by the effects of higher temperatures. Warming may result from more radiation and may lead to lower vapor pressure deficits if more evaporated water from the tropics is advected in, as well as increased photosynthesis, which will increase stomatal conductance. However, warming can just as easily result in higher vapor pressure deficits and reduced photosynthesis if moisture limitation is an issue. Elevated $\mathrm{CO}_{2}$ therefore can increase stomatal conductance directly or indirectly through higher photosynthetic rates (Figure 1). Higher photosynthetic rates may result in higher LAI, which allows for more transpiration and canopy interception of water but less soil evaporation due to shading. Soil evaporation is also dependent upon solar radiation and vapor pressure but is regulated by soil resistance, which is related to soil moisture [Shuttleworth and Wallace, 1985].

[5] The effect of elevated $\mathrm{CO}_{2}$ on plants has both a direct fertilization effect on gross primary production (GPP) of $\mathrm{C} 3$ plants and an effect on stomatal conductance (according to the Ball et al. [1987] formulation). In dry environments, $\mathrm{CO}_{2}$ fertilization is enhanced. Under drier conditions, the $\mathrm{Ci} / \mathrm{Ca}$ is lower because of reduced stomatal conductance. While the overall GPP is greater at a moist site, the relative increase in GPP is larger at a dry site, given our formulation of $\mathrm{Ci}$. Added to this direct atmospheric effect, moisture feedbacks due to increased water use efficiency (WUE) will also be larger at drier sites, leading to a further potential $\mathrm{CO}_{2}$ enhancement of GPP. Therefore, the effect of $\mathrm{CO}_{2}$ on stomatal conductance should be smaller relative to $\mathrm{CO}_{2}$ fertilization in more arid regions of the world.

[6] Recent modeling experiments have focused on plant physiological controls of streamflow, including stomatal conductance and LAI, and how these factors respond to changing climate. Some studies have attributed increased runoff during the 20th century to the reduction in stomatal conductance resulting from higher atmospheric $\mathrm{CO}_{2}$ levels [Gedney et al., 2006]. Others have projected that reduced stomatal conductance will also increase runoff in the future [Betts et al., 2007]. Whether rising $\mathrm{CO}_{2}$ levels in the 20th century can be linked to increased runoff from the effect $\mathrm{CO}_{2}$ on stomatal conductance has been questioned. Piao et al. [2007] used a modeling approach to demonstrate that accounting for the effect of elevated $\mathrm{CO}_{2}$ on increased LAI results in a net decrease in runoff and that increases in observed runoff are attributable to climate and land use changes. Krakauer and Fung [2008] show that increased runoff is attributable to increases in precipitation and that the effect of $\mathrm{CO}_{2}$ on stomatal conductance is countered by increasing evaporation, particularly where cold season precipitation dominates, such as the Pacific Northwest.

[7] Unlike these earlier studies, Felzer et al. [2009] have shown the importance of carbon-nitrogen interactions to available water in eastern temperate forests of the United States. Nitrogen limitation reduces photosynthetic rates. Models that fail to account for the effects of nitrogen overestimate plant growth [Sokolov et al., 2008; Thornton et al., 2009]. By reducing photosynthetic rates, nitrogen limitation has the potential to lower stomatal conductance and transpiration and therefore increase runoff (Figure 1). This effect of elevated $\mathrm{CO}_{2}$ on stomatal conductance more than compensates for the increased transpiration and reduced runoff resulting from $\mathrm{CO}_{2}$ fertilization.

[8] Here we consider the importance of carbon-nitrogen interactions in the western United States and the importance of drivers in a region traditionally considered to be water limited either seasonally or annually. Nitrogen limitation is, to a large degree, regulated by the amount of available inorganic nitrogen for plant uptake, which depends upon sufficient net nitrogen mineralization rates. Other studies have shown increased net nitrogen mineralization and reduced nitrogen limitation as a result of warming [Fenn et al., 2003; Magnani et al., 2007; Melillo et al., 2002, 2011; Rustad et al., 2001; Thomas et al., 2010; Vourlitis et al., 2007; Zaehle et al., 2010] and also increased nitrogen use efficiency resulting from increased $\mathrm{CO}_{2}$ [Finzi et al., 2006; Luo et al., 2004]. Modeling studies have confirmed the increase in net nitrogen mineralization [Sokolov et al., 2008; Thornton et al., 
2009]. Increased moisture increases mineralization rates by increasing decomposition rates up to a point, after which saturating conditions are limiting, as heterotrophic respiration is less under anoxic conditions [Alexander, 1977; Clark, 1967]. Several studies have shown how soil moisture limits nitrogen mineralization in the West [Arnone and Bohlen, 1998; Clark, 1990; Pfeifer-Meister and Bridgham, 2007]. While many modeling studies have focused on the role of moisture limitation on carbon dynamics in the West [e.g., Running and Nemani, 1991], few have considered the effects of moisture on nitrogen dynamics. Although nitrogen deposition rates are having an increasingly large effect on reducing nitrogen limitation [Fenn et al., 2003; Magnani et al., 2007; Thomas et al., 2010; Vourlitis et al., 2007], we are not explicitly considering air pollution effects in this study.

[9] Accurately modeling these processes in the western United States requires accounting for the unique western vegetation and topography. The widespread existence of $\mathrm{C} 4$ plants in shrubland and grassland biomes limits the effect of $\mathrm{CO}_{2}$ fertilization. The steep topographic gradients require a high enough resolution to capture accurate temperature and precipitation. This study uses a biogeochemistry model, TEM-Hydro, to explore the potential effects of rising $\mathrm{CO}_{2}$, warming, changing soil moisture and nitrogen limitation on primary production, transpiration and runoff from natural ecosystems (forest, grasses, and shrubs) of the western United States. Warming and reduced precipitation in the West will lead to drier soils, while elevated $\mathrm{CO}_{2}$ should increase water availability. We use the model to separate out the effects of warming from precipitation and $\mathrm{CO}_{2}$ fertilization from the effect of $\mathrm{CO}_{2}$ on stomatal conductance, so that we can explore the role of warming and moisture on nitrogen limitation. In section 2 , we review the recent revisions to TEM-Hydro, the development of the forcing data sets, and the experimental design. Model validation against eddy covariance, leaf area index (LAI) and streamflow measurements are discussed in section 3, which illustrate how elevated $\mathrm{CO}_{2}$, warming, and reduced precipitation, and their effects on $\mathrm{N}$ limitation and moisture limitation, affect water use efficiency and runoff in western forests, shrublands, and grasslands.

\section{Methods}

\subsection{Model Description}

[10] TEM-Hydro was developed specifically to account for carbon-nitrogen-water interactions through the role of stomatal conductance in transpiration and the uptake of $\mathrm{CO}_{2}$ and $\mathrm{O}_{3}$. To accomplish this task, we developed a multiple pool model of vegetation carbon and nitrogen in leaves, active and inactive stem tissues (e.g., sapwood and heartwood), fine roots, and a labile pool for storage. Leaf area index (LAI) is calculated as the product of the leaf carbon and the biome-dependent specific leaf area. Fluxes into and out of the pools include photosynthesis, nitrogen uptake, respiration, litter fall, and allocation. Each compartment, with the exception of the labile pool, has a plant functional type (PFT)-dependent $\mathrm{C}: \mathrm{N}$ ratio. The hydrology is based on a simple one-layer bucket model [Vörösmarty et al., 1989], employing the Shuttleworth and Wallace [1985] approach to determine evapotranspiration. The stomatal conductance, used to calculate the transpiration, is based on the Ball et al.
[1987] approach and is therefore a function proportional to GPP and relative humidity and inversely proportional to atmospheric $\mathrm{CO}_{2}$ levels. Structural changes in LAI increase the transpiration by scaling the stomatal conductance to canopy conductance as well as increasing the canopy interception but decrease the soil evaporation due to shading. A complete description of the model is given by Felzer et al. [2009] and outlined in Figure 2 with additional details outlined in Figures S3, S4 and S5 of the auxiliary material. ${ }^{1}$ Calibration, parameter, and target values are given in Tables S1, S2a, S2b, and S3, respectively. The model was originally developed and validated for temperate forest ecosystems of the eastern United States [Felzer et al., 2009] but has been modified to include grass and shrub biomes of the western United States. Other changes were introduced to improve model performance irrespective of biome type.

[11] In order to better model shrubs and grasses, we accounted for a mixture of $\mathrm{C} 3$ and $\mathrm{C} 4$ shrubs (consistent with the Curlew, Utah, calibration site) and C4 grasses (consistent with the Pawnee, Colorado, calibration site) by adjusting the values of model parameters to account for lower $\mathrm{CO}_{2}$ fertilization levels in $\mathrm{C} 4$ plants. The $\mathrm{CO}_{2}$ fertilization effect is assumed to be a hyperbolic function with a half-saturation constant derived from the literature [Curtis and Wang, 1998; Gunderson and Wullschleger, 1994; Kimball, 1983; Norby et al., 1999, 2005]. We lowered the half saturation constant for $\mathrm{CO}_{2}$ fertilization from 200 for forests to 120 for shrubs and 40 for grasses. As described in section 3.1, we also increased rooting depth of shrubs from 2.5 to $5.0 \mathrm{~m}$ and lowered rooting depth of grasses from 2.5 to $1.5 \mathrm{~m}$. Additional changes made to grasslands to better correlate with eddy covariance data are described more fully in section 3.1 in order to provide the reader with the context for these changes.

[12] The relevant changes to TEM-Hydro since the work by Felzer et al. [2009] include adjustments made to handle reduced productivity or too excessive evapotranspiration under arid conditions in the western United States, which were motivated by trying to better match the watershed and eddy covariance data. These changes include allowing additional carbon and nitrogen allocation to roots and stems in drought conditions, limiting soil evaporation under extremely dry conditions, and lowering the optimal temperature for photosynthesis in cold grasslands to allow for greater productivity. Canopy interception and evaporation of the intercepted water is now explicitly calculated. Determination of nitrogen-limiting conditions is now tested against supply and demand $\mathrm{C}: \mathrm{N}$ and the ratio of labile $\mathrm{C}: \mathrm{N}$, with direct down regulation of GPP or nitrogen uptake. We also now use temperature range data to determine day versus night energy fluxes and photosynthesis. A climatological data set of wind speed is now used to determine aerodynamic resistances for evapotranspiration (in the previous version we used constant values for these resistances). A base daily time step is used for our numerical solutions, with monthly forcing data. The daily time step is used in the Bogacki-Shampine 2-3 order Runge-Kutta method and is often used subdaily in the adaptive integrator. We have introduced this change to allow a future transition to daily data (or coupling with daily output from a climate model)

\footnotetext{
${ }^{1}$ Auxiliary materials are available in the HTML. doi:10.1029/ 2010JG001621.
} 


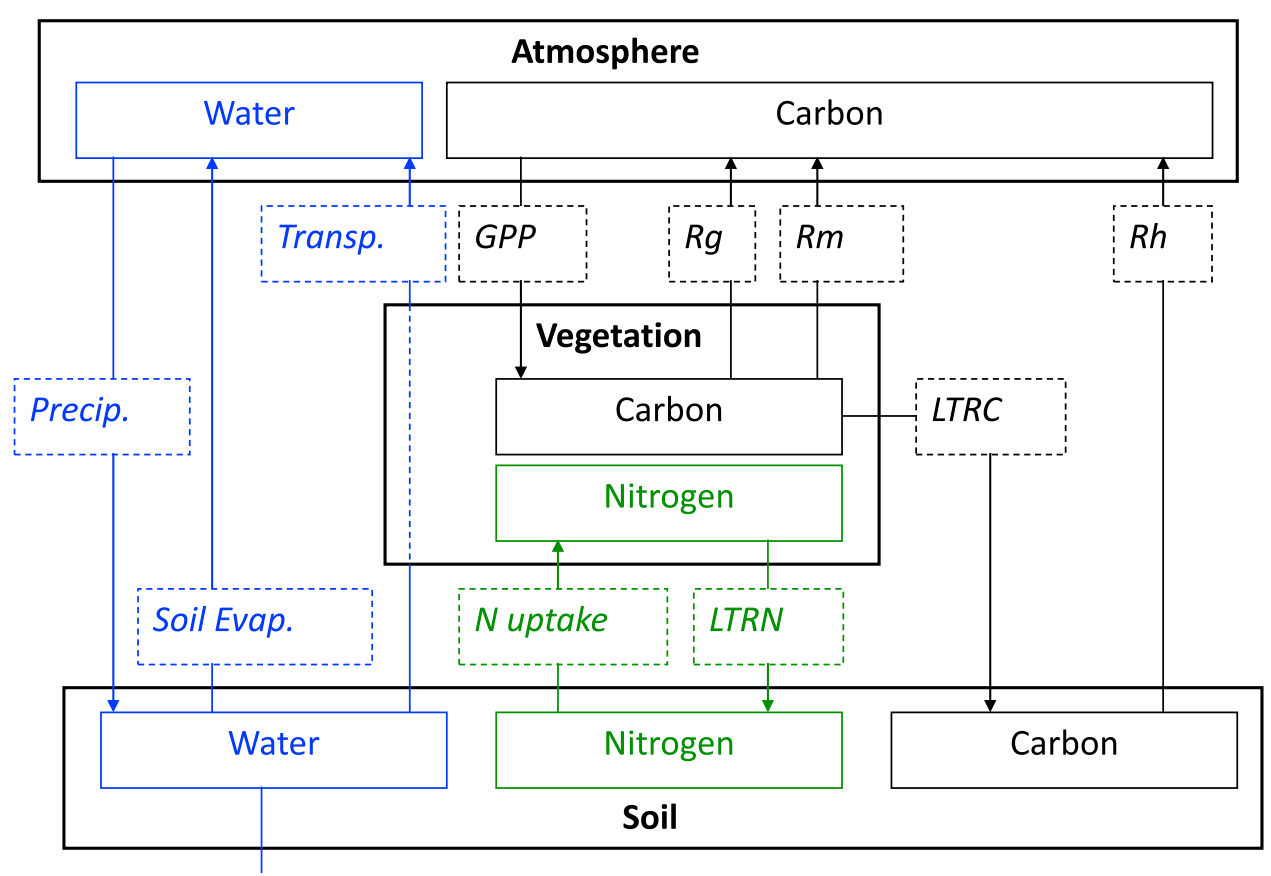

Figure 2. TEM-Hydro overview. TEM-Hydro considers interactions between the atmosphere, vegetation, and soil. Carbon fluxes between the atmosphere and vegetation include GPP (gross primary productivity) and growth and maintenance respiration ( $\mathrm{Rg}, \mathrm{Rm})$. LTRC and LTRN are the carbon and nitrogen litter fall rates, respectively, from vegetation to soil. Heterotrophic respiration (Rh) represents microbial soil decomposition, and $\mathrm{N}$ uptake represents the uptake of inorganic nitrogen from the soil. See Text S1 for details on fluxes and pools of carbon, nitrogen, and water.

and to ensure numerical stability of some outputs. In this study, Terrestrial Ecosystem Model (TEM) is still based on monthly climatology, so that additional model testing will be required before using daily data with the model. Equilibration is now done with respect to a variable climate rather than a climatic mean. Details are described in Text S1 in the auxiliary material.

[13] Since the effect of warming and drying on nitrogen uptake are important for this study, it is important to understand how these terms are treated in TEM-Hydro under nitrogen-limiting conditions. Nitrogen uptake is described by Felzer et al. [2009] and depends upon root biomass, available inorganic nitrogen, volumetric soil moisture, ozone, and temperature. The temperature function is based the LaRS [Hanson et al., 2004] formulation, which allows for a slower increase in respiration at higher temperatures, with a reference rate dependent on the optimal temperature. Available inorganic nitrogen depends upon the net nitrogen mineralization rate, which, in turn, depends upon heterotrophic respiration [Raich et al., 1991]. Heterotrophic respiration is influenced by the amount of soil organic carbon, the $\mathrm{C}: \mathrm{N}$ ratio of the soil organic matter, soil moisture and air temperature [McGuire et al., 1997; Raich et al., 1991; Tian et al., 1999]. The moisture function has been revised to now account for soil texture (see Text S1 in the auxiliary material for details) but still depends upon volumetric soil moisture. The temperature function follows the Lloyd and Taylor [Taylor et al., 1994] sigmoidal formulation and does not allow for acclimation. Therefore, warming will increase heterotrophic respiration rates, which increases net nitrogen mineralization, thereby increasing the amount of inorganic nitrogen that is available for uptake by plants. Warming also increases the rate of nitrogen uptake by plants. In contrast, drying will limit heterotrophic respiration and net nitrogen mineralization and hence will reduce the amount of nitrogen available for plant uptake. In addition, drying reduces the rate of nitrogen uptake by plants. Thus, warming increases nitrogen uptake if adequate soil moisture is available whereas drying reduces nitrogen uptake.

[14] In a review of $\mathrm{CO}_{2}$ fertilization effects on forest ecosystems, Huang et al. [2007] show that $\mathrm{CO}_{2}$ fertilization is largest in warm, moderately drought-stressed forests that are not nitrogen limited. Trees in moderately arid environments benefit most from the increased WUE resulting from the lower stomatal conductance. In dry shrublands studied at the Mojave Free Air $\mathrm{CO}_{2}$ Enrichment (FACE) site in Nevada, high $\mathrm{CO}_{2}$ levels reduced stomatal conductance under moist conditions and only for certain shrubs [Pataki et al., 2000]. In other cases, elevated $\mathrm{CO}_{2}$ led to reduced transpirational surface area per sapwood area (or more water carrying capacity per unit leaf area), resulting in higher leaf-specific hydraulic conductivity (lsc) and either increasing or unchanged stomatal conductance. In TEM-Hydro, we have incorporated a drought-stress function on GPP that does decrease with increased leaf specific conductivity, thus allowing for larger GPP and gs. However, elevated $\mathrm{CO}_{2}$ does not necessarily lead to increased lsc, and the effect of $\mathrm{CO}_{2}$ on stomatal conductance is dominant.

[15] Modeling evapotranspiration in a warm and dry environment like the lowland shrublands requires ensuring that existing plants have ample access to water. Because nearly all the precipitation that falls in these environments is 


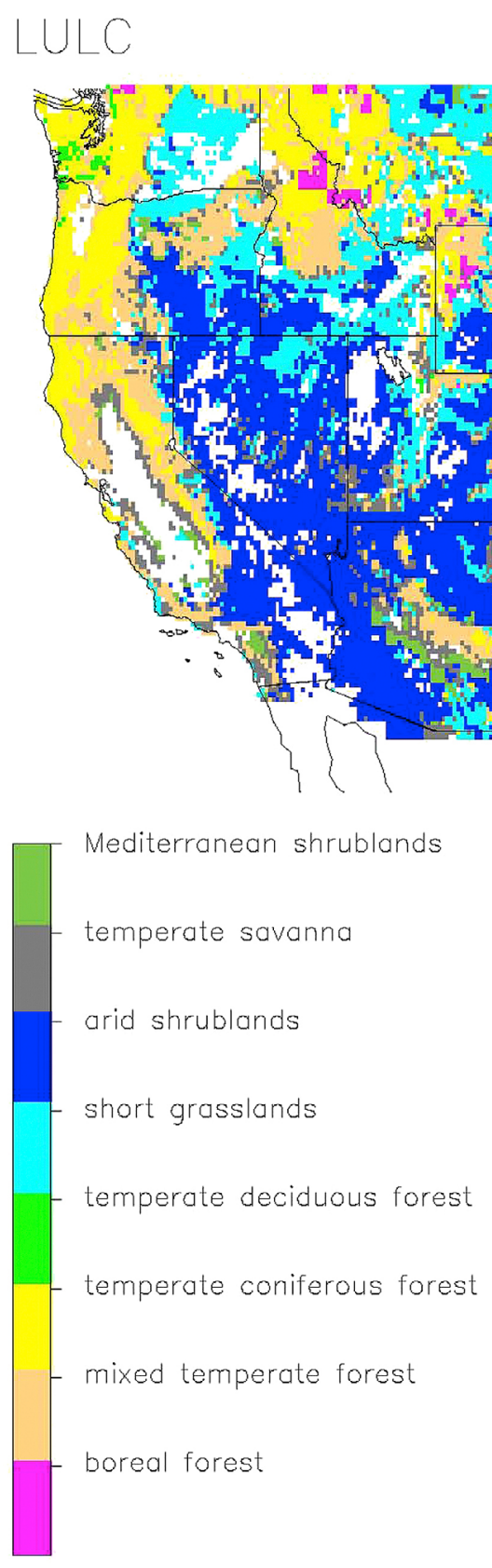

Figure 3. Land use and land cover data set used to force TEM-Hydro. White areas represent croplands, urban areas, deserts, and Mediterranean shrublands, which were not included in this study. The data set is derived from the $1 \mathrm{~km}$ Global Land Cover Classification data set [Hansen et al., 2000; DeFries et al., 2000], which is based on the NASA/NOAA Pathfinder land data set and is a snapshot of land use and land cover from 1981 to 1994 . We have scaled the data to $1 / 8^{\circ}$ resolution.

evaporated [Krakauer and Fung, 2008], plants will not survive without access to groundwater. There is observational evidence for deep rooting systems in arid environments [Canadell et al., 1996], with shrubs attaining a mean maximum rooting depth of $5.2 \mathrm{~m}$ and as deep as $40 \mathrm{~m}$. Although these tap roots are only a small fraction of the entire rooting systems, they are important for water transport and especially important for allowing water extraction during dry periods. There is also evidence that hydraulic redistribution may allow these roots to extract water at night to release to the shallow soil layer for other roots to use during the day [Richards and Caldwell, 1987]. Most models use rooting depths of $0.5-2 \mathrm{~m}$ to account for maximum density of roots, but these rooting depths fail to account for the ability to access deeper sources of groundwater. In particular, deep-rooted phreatophytes can account for significant water uptake for plant use and transpiration in shrub ecosystems. Unland et al. [1998] found that evapotranspiration in the Santa Cruz River in southern Arizona is dominated by riparian phreatophytes, accounting for as much as half of the total nonirrigated evapotranspiration (ET). Domingo et al. [1999], testing a model in SE Spain, also found that accounting for the total soil water content, including deep water, was crucial to calculating the correct ET. We therefore use a rooting depth of $5 \mathrm{~m}$ for shrubs.

\subsection{Data Set Development}

[16] Input transient forcing data for TEM-Hydro includes fractional cloud cover (used to derive photosynthetically active radiation, PAR), surface temperature, precipitation, vapor pressure, diurnal temperature range, ozone, and $\mathrm{CO}_{2}$. Required static data sets include vegetation cover and soil texture. Monthly data sets were developed for the western conterminous United States (west of $105^{\circ} \mathrm{W}$ ) at a spatial resolution of $1 / 8^{\circ}$ longitude $\times 1 / 8^{\circ}$ latitude. This resolution was chosen based on the World Climate Research Programme's (WCRP's) Coupled Model Intercomparison Project phase 3 (CMIP3) multimodel data set, which is bias corrected and spatially downscaled climate projections derived from CMIP3 data and served at http://gdo-dcp. ucllnl.org/downscaled_cmip3_projections/[Maurer et al., 2007]. The land use and land cover data are developed from the $1 \mathrm{~km}$ Global Land Cover Classification data set [DeFries et al., 2000; Hansen et al., 2000], which is based on the NASA/NOAA Pathfinder Advanced Very High Resolution Radiometer (AVHRR) land data set. This data set is a snapshot of land use and land cover from 1981 to 1994. There are 13 land types that we have converted to TEM vegetation, with further detail from the TEM vegetation where needed. For this study, we are not modeling cropland, urban areas, desert, or Mediterranean shrubland (which cover a limited area and for which we need to develop a better calibration data set). Therefore, the data set represents contemporary land cover, with the grid cells dominated by human land use excluded. The western United States consists of forest (temperate deciduous, temperate coniferous, mixed temperate, and boreal), short grassland, and arid shrubland and contains 16,508 grids at the $1 / 8^{\circ}$ resolution used by the model after being aggregated from the $1 \mathrm{~km}$ resolution (Figure 3).

[17] Historical climate data sets (1904-2000) are developed from the Precipitation-elevation Regressions on Independent Slopes Model (PRISM) downscaled data at $1 / 24^{\circ}$ resolution [Daly et al., 1994]. The downscaling is based on regionally dependent empirical relationships between DEMbased slope, elevation, and wind with precipitation. These data include monthly maximum and minimum temperature, dewpoint temperature, and precipitation and are used to create TEM input data sets of mean temperature, diurnal 


\section{JJA Surface Temperature Difference: A2 (2090-2099) - (2001-2010)}

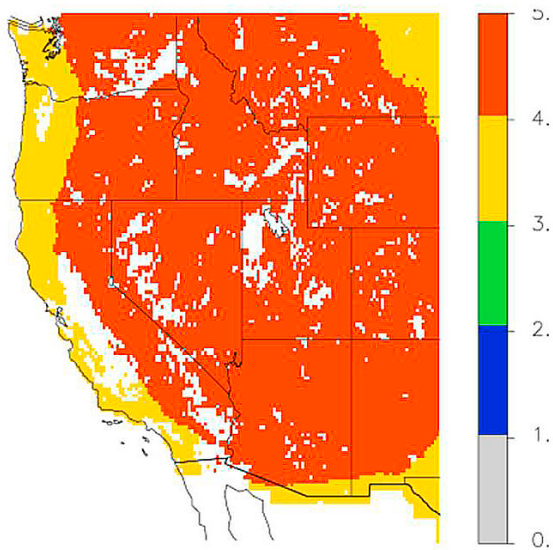

a
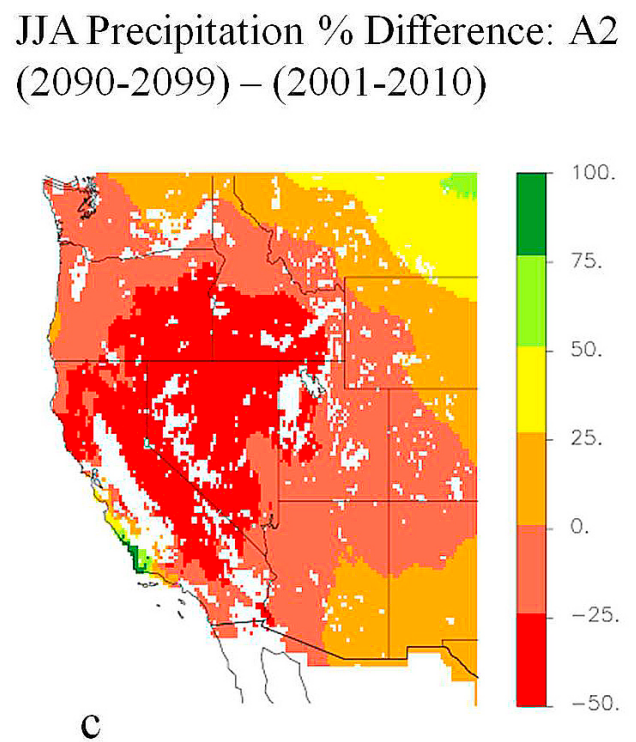

\section{DJF Surface Temperature Difference: A2 (2090-2099) - (2001-2010)}



b

Figure 4. Changes between the future (2090-2099) and present baseline (2001-2010) for (a) summer (JJA) surface temperature, (b) winter (DJF) surface temperature, (c) summer precipitation, and (d) winter precipitation.

temperature range, vapor pressure, and precipitation by aggregating up to the $1 / 8^{\circ}$ resolution. Clouds are interpolated from the half degree Climatic Research Unit version 2.0 (CRU2.0) data set [Mitchell et al., 2004]. Surface ozone is interpolated from the U.S. AOT40 data set developed by Felzer et al. [2004] based on EPA CASTNET and AQS ozone data. All interpolations are done using a nearestneighbor approach.

[18] Future scenario climate from 2000 to 2099 is based on the IPCC A2 scenario [IPCC, 2007] from NCAR CCSM3.0 [Collins et al., 2006]. The A2 scenario was chosen because it is a particularly warm scenario and therefore provides a good test case for a sensitivity experiment. Recent evidence [Allison et al., 2009] also shows that we are most likely on a warmer scenario based on recent observations. The surface temperature and precipitation are taken from the CMIP3 data at $1 / 8^{\circ}$ resolution [Maurer et al., 2007]. Substantial warming occurs everywhere (Figure 4), but in winter the largest warming occurs in the Southwest, an area largely covered by shrubs. While summer precipitation is greatly reduced throughout most of the West, in winter, many areas receive more precipitation than at present. The annual precipitation is reduced in all biomes (Table 1). Note that while vapor pressure increases, so does vapor pressure deficit, so the air is actually getting drier. Photosynthetically active radiation (PAR) also increases in each biome but especially in shrublands. Since there are no future downscaled minimum and maximum temperatures, the diurnal temperature range is held constant as the mean temperature range for the historical data from 1904 to 2000. Clouds, vapor pressure and AOT40 
Table 1. Current and Projected Changes Over the 21 st Century ${ }^{\mathrm{a}}$

\begin{tabular}{|c|c|c|c|c|c|}
\hline Biome & $\begin{array}{l}\text { TAIR } \\
\left({ }^{\circ} \mathrm{C}\right)\end{array}$ & $\begin{array}{c}\text { PAR } \\
\left(\mathrm{W} \mathrm{m}^{-2}\right)\end{array}$ & $\begin{array}{c}\text { PREC } \\
(\mathrm{mm})\end{array}$ & $\begin{array}{l}\text { VPR } \\
(\mathrm{kPa})\end{array}$ & $\begin{array}{l}\text { VPD } \\
(\mathrm{kPa})\end{array}$ \\
\hline \multicolumn{6}{|l|}{ Western forests } \\
\hline Current & 6.8 & 996.5 & 1039.8 & 6.2 & 3.7 \\
\hline$\Delta$ & 3.9 & 4.8 & -84.5 & 1.6 & 1.4 \\
\hline \multicolumn{6}{|c|}{ Western shrublands } \\
\hline Current & 11.7 & 1132.4 & 285.1 & 6.2 & 7.6 \\
\hline$\Delta$ & 5.1 & 14.8 & -38.2 & 1.7 & 3.7 \\
\hline \multicolumn{6}{|c|}{ Western grasslands } \\
\hline Current & 7.5 & 1009.2 & 412.6 & 5.8 & 4.6 \\
\hline$\Delta$ & 4.7 & 0.7 & -15.2 & 1.5 & 2.3 \\
\hline \multicolumn{6}{|c|}{ Total western biomes } \\
\hline Current & 9.1 & 1061.8 & 555 & 6.1 & 5.5 \\
\hline$\Delta$ & 4.6 & 8.34 & -49 & 1.6 & 2.5 \\
\hline
\end{tabular}

${ }^{a}$ Mean monthly air temperature (TAIR), mean monthly cloudiness, (CLDS), mean annual precipitation (PREC), mean annual vapor pressure (VPR), and mean annual vapor pressure deficit (calculated from TAIR and VPR) for natural biomes in the western United States.

are downscaled directly from the half degree data sets developed for Felzer et al. [2009]. The future ozone levels are held constant at year 2000 AOT40 values [Felzer et al., 2007].

[19] Static data sets include wind speed, soil texture, and elevation. These data are downscaled from the $0.5^{\circ} \times 0.5^{\circ}$ resolution to the $1 / 8^{\circ} \times 1 / 8^{\circ}$ resolution using a nearestneighbor approach. The wind speed is from CRU2.0. Soil texture and elevation are based on the standard TEM data sets [Felzer et al., 2004].

\subsection{Experimental Design}

[20] To evaluate the importance of various environmental factors on GPP, evapotranspiration and runoff, we conducted six sensitivity experiments (Table 2). To obtain starting conditions for these experiments, we first ran a simulation with historical (1904-2000) climate change and $\mathrm{CO}_{2}$. Model validations were performed against this run.

[21] The first simulation explores the effects of climate alone (via the precipitation, temperature, and other climate anomalies), holding $\mathrm{CO}_{2}$ concentrations constant over the 21 st century. To look more closely at the effects of varying air temperature and precipitation independently, we next conduct two simulations similar to the climate alone simulation. In the first of these two simulations, we allow air temperature to vary according to the A2 emissions scenario but use the baseline values for the other climate variables. In the second simulation, we allow precipitation to vary and use baseline values for the other climate variables. The fourth simulation incorporates elevated $\mathrm{CO}_{2}$ according to the A2 emissions scenario but with a constant climate. The constant climate is the detrended climate from 1971 to 2000 repeated three times followed by the 1971-1980 climate. This simulation is repeated without the effect of $\mathrm{CO}_{2}$ on stomatal conductance, so $\mathrm{CO}_{2}$ is kept constant in the stomatal subroutines at the year 2000 value. The final simulation includes both climate and $\mathrm{CO}_{2}$ change, including the effect of $\mathrm{CO}_{2}$ on stomatal conductance. We also repeat the sensitivity experiments for the eastern U.S. forests examined by Felzer et al. [2009] at the $0.5^{\circ} \times 0.5^{\circ}$ resolution but with the new version of TEM-Hydro. This allows a more appropriate comparison of the ecosystem responses to climate change between eastern and western forests of the United States.

[22] To evaluate results, percent differences between future (2080-2099) and historical (1981-2000) periods are calculated from model output. Error bars for statistically significant percent differences are calculated as standard errors, according to the following equations [Taylor, 1982]:

$$
\begin{gathered}
\operatorname{sterr}_{f}=\frac{\sigma_{f}^{2}}{n^{0.5}} \\
\operatorname{sterr}_{p}=\frac{\sigma_{p}^{2}}{n^{0.5}} \\
\text { error }=\left(\frac{\operatorname{sterr}_{f}^{2}}{\bar{x}_{f}}+\frac{\operatorname{sterr}_{p}}{\bar{x}_{p}}\right)^{(0.5)} \times 100
\end{gathered}
$$

where $f$ is the future period (2080-2099), $p$ is the present period (1981-2000), $x$ is climate variable, $n$ is number of years (20), sterr is standard error, and error is final error bars values.

\section{Results}

\subsection{Evaluation of Model Hydrology and Carbon}

[23] We have compared model estimates of ET and net ecosystem production (NEP; NEP $=-\mathrm{NEE}$, net ecosystem exchange) to eddy covariance measurements at several grassland sites in the western United States. These sites include two semiarid grasslands in Arizona (Audubon and Kendall) and two Mediterranean grasslands in California (Tonzi and Vaira Ranch), one of which (Tonzi) also contains up to $40 \%$ oak trees within the tower footprint. The other site (Fort Peck, Montana) is a cool season grassland. We have aggregated the half hourly eddy covariance data to monthly for the sake of this comparison. Meteorological

Table 2. Design of Sensitivity Experiments ${ }^{\mathrm{a}}$

\begin{tabular}{llcc}
\hline & & Stressors & \\
\cline { 2 - 4 } \multicolumn{1}{c}{ Simulation } & \multicolumn{1}{c}{ Climate Change } & $\begin{array}{c}\text { Effect of CO } \\
\text { on } \\
\text { Stomatal Conductance }\end{array}$ \\
\hline Climate & A2: TAIR, PREC, CLDS, VPR & $\mathrm{CO}_{2}$ & Yes \\
TAIR & A2: TAIR; Baseline: PREC,CLDS, VPR & Constant & Yes \\
PREC & A2: PREC; Baseline: TAIR, CLDS, VPR & Constant & Yes \\
$\mathrm{CO}_{2}$ & Baseline: TAIR, PREC, CLDS, VPR & Increasing & Yes \\
$\mathrm{CO}_{2}$ (no gs) & Baseline: TAIR, PREC, CLDS, VPR & Increasing & No \\
$\mathrm{Climate}+\mathrm{CO}_{2}$ & A2: TAIR, PREC, CLDS, VPR & Increasing & Yes \\
\hline
\end{tabular}

${ }^{\mathrm{a}}$ Climate change represented by the IPCC A2 scenario or baseline climate (detrended climate for the period 1971-2000); climate variables include air temperature (TAIR), precipitation (PREC), cloudiness (CLDS) and vapor pressure (VPR); $\mathrm{CO}_{2}$ is consistent with the IPCC A2 scenario or kept constant at $369.2 \mathrm{ppmv}$. 
data prior to the eddy covariance measurement period are taken from CRU2.0 and are bias corrected to the eddy covariance values.

[24] In order to prevent the vegetation from dying or undergoing severe stress at the semiarid grasslands, we applied pulse precipitation. Normally, TEM-Hydro is forced by monthly climate data, although the numerical time step is daily, with the effective time step even lower due to the adaptive integrator. Therefore, the precipitation is distributed throughout the month and effectively is a continuous drizzle. While this scheme does not pose problems at forests or well watered grassland sites, the soil moisture supply never accumulates enough to sustain the vegetation at these semiarid grasslands. Therefore, we imposed a single precipitation pulse at the start of each month by adding precipitation to the soil moisture prior to entering the numerical integration. This change enabled vegetation to survive at these sites, so in our validation, we have applied the pulse precipitation to all of the grassland sites. At Audubon we are capturing the seasonal variability in both ET and NEP (Figure 5), although NEP values are not low enough in dry summers. During this period, TEM is not capturing large enough pulses of ecosystem respiration that occur with the precipitation pulses, even when the grass is dead [Xu and Baldocchi, 2004]. Both modeled and observed values are small sources (Table 3) but they are variable from year to year, depending upon the monsoonal rains [Krishnan et al., 2008]. At Kendall (Figure 6), the modeled ET matches well with the observations, although the modeled NEP does not capture the variability early on. Both modeled and observed values are small sinks (Table 3 ), though there is considerable year-to-year variability. While both sites experienced severe drought in 2004 and 2005, the native grasses in Kendall actually died and were replaced by invasive broadleaved forbs with drought alleviation in 2006 [Scott et al., 2010]. This ecosystem disruption during the drought years explains why it is so difficult to model that period.

[25] The majority of grasslands in the western United States are cool season grasses in the northern Great Plains. These sites experience most of their precipitation during the summer [Zhang et al., 2010]. TEM simulates the seasonal ET well (Figure 7). While the NEP correlation is not as good, we do capture some of the major peaks and valleys. Also, both observations and model agree that Fort Peck is a small carbon source, consistent with the prevalence of drought conditions [Zhang et al., 2010].

[26] The Mediterranean grasslands in California occur in a climate of virtually no summer precipitation. At these sites, both the peak carbon sink and peak ET occur in late spring, rather than summer. The single pool soil model in TEM produces peak ET in summer since we are not able to use up all the precipitation at the surface within a single month and thus prevent it from becoming part of the soil moisture pool for future months. We have introduced three changes to correct this problem. The first is to decrease rooting depth from 2.5 to $1.5 \mathrm{~m}$, which limits the water capacity of the bucket, thereby allowing our moisture stress function to vary more readily with changes in precipitation. This change is consistent with the shallow rooting depths observed by $X u$ and Baldocchi [2004]. The second change is a new moisture stress function for GPP, which is more sensitive to drought conditions (described more fully in Text S1). The final change is conditional for extremely arid conditions, in which we set the canopy conductance and GPP to zero if the sum of soil moisture and precipitation are below a certain threshold. These changes are applied to all grasslands because they did not significantly impact the other sites.

[27] With these changes, the seasonal ET is in good agreement with measurements at Vaira and Tonzi (Figures 8 and 9), except for an underestimation of the summer peaks at Tonzi. We do not account for phreatophytic blue oaks at Tonzi that may access local groundwater during the dry summer months [Miller et al., 2010]. The NEPs at both sites are in good agreement with measurements in summer but too low in winter. The eddy covariance values are a larger sink at both sites than the modeled estimates (Table 3). Xu and Baldocchi [2004] observed that during the dry summers, ecosystem respiration is primarily from the recalcitrant carbon pool and has a lower temperature sensitivity, so that Q10 is less. The low TEM NEPs in summer result from overly high values of plant and microbial respiration. To correct this problem, we would need to incorporate multiple soil decomposition pools to allow for separate Q10 values for each pool.

[28] We only have a limited number of forest sites in the West, and they each present difficulties for validation, but monthly means are presented in Table 3 and annual means in Figure 10. The eddy covariance NEPs for each of these sites is a much larger carbon sink than TEM is able to model. Wind River crane, Washington, is an old growth forest dominated by Douglas Fir and Western Hemlock. The eddy covariance values show it to be a strong carbon sink, with annual values (Figure 10) close to $400 \mathrm{~g} \mathrm{C} \mathrm{m}^{-2} \mathrm{yr}^{-1}$ from 1999 to 2006. TEM-Hydro assumes that fully mature forests have an annual NEP close to zero, so we will never be able to model this kind of sink. Field and Kaduk [2004] discuss how different measurement and modeling methods at Wind River can result in significantly smaller carbon sinks than the eddy covariance values. Biometric estimates [Campbell et al., 2004; Harmon et al., 2004] show a much smaller sink, averaging $20 \mathrm{~g} \mathrm{C} \mathrm{m}^{-2} \mathrm{yr}^{-1}$ from 1995 to 1999 , when the eddy covariance values showed sinks from 150 to $220 \mathrm{~g} \mathrm{C} \mathrm{m}^{-2} \mathrm{yr}^{-1}$. Falk et al. [2008] also show that from 1999 to 2004 this site varies from strong sinks to weak-moderate sources, whereas the eddy covariance annual values are strong sinks every year. The annual TEM sink is $63 \mathrm{~g} \mathrm{C} \mathrm{m}^{-2} \mathrm{yr}^{-1}$, much closer to the biometric estimates. In spite of the differences in NEP, the ET matches well with the observed value.

[29] The two pondersosa pine forests are Blodget Forest, California, and Metolius old pine site, Oregon. Blodget was planted in 1990, so we have accounted for that disturbance.

Figure 5. Comparison of temporal patterns (2002-2006) in TEM-Hydro and eddy covariance estimates at the Audubon grassland (Arizona) site for (a) monthly ET and (b) monthly NEP; and comparisons of model and observed estimates for (c) monthly ET $\left(\mathrm{m}=1.4, \mathrm{~b}=-4.9, \mathrm{r}^{2}=0.88, \mathrm{p}<0.01\right)$ and $(\mathrm{d})$ monthly NEP $\left(\mathrm{m}=0.60, \mathrm{~b}=0.84, \mathrm{r}^{2}=0.53, \mathrm{p}<0.01\right)$. Points above the 1:1 line are model overestimates; points below the 1:1 line are model underestimates. 

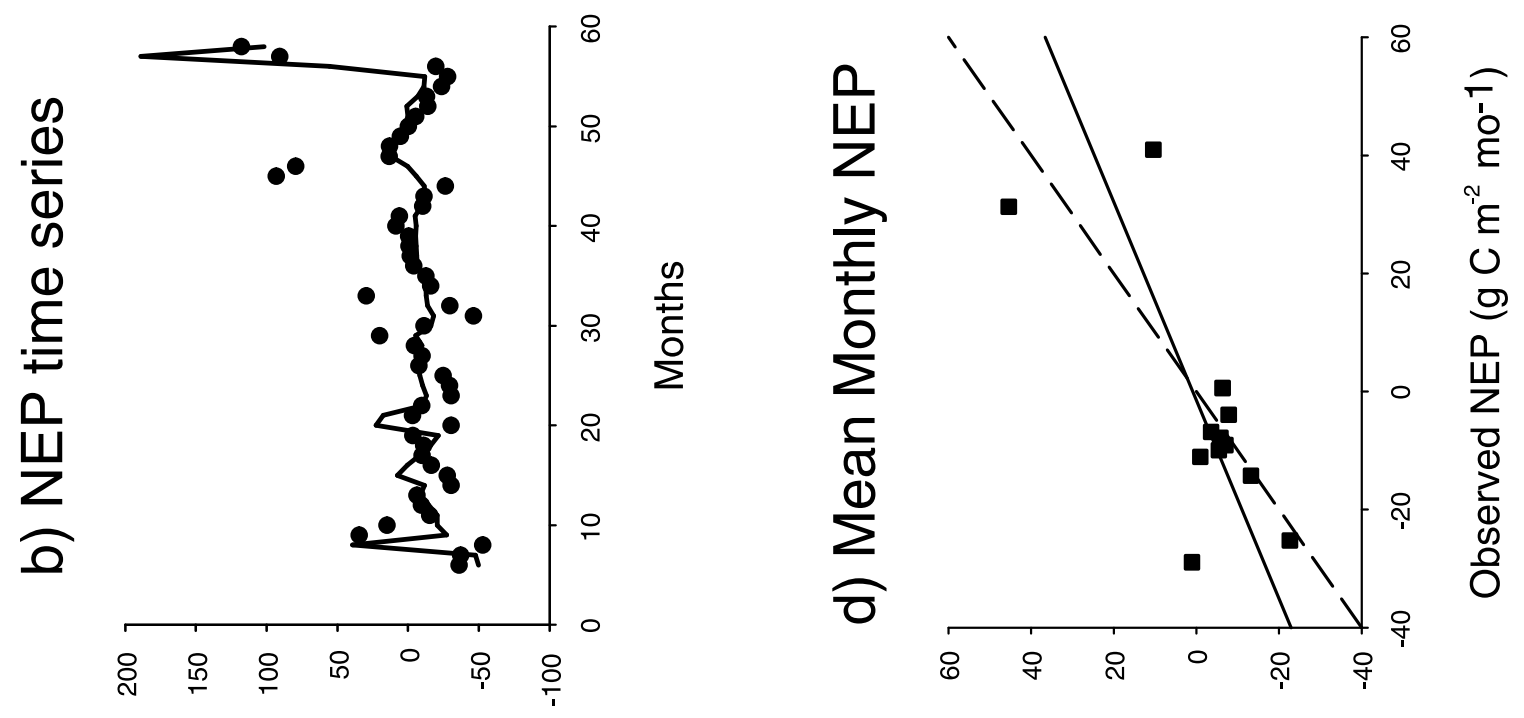

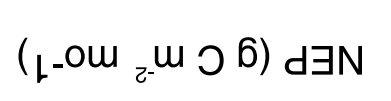





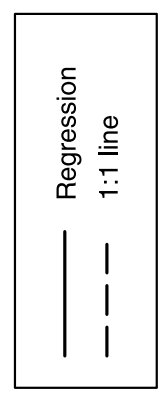

no
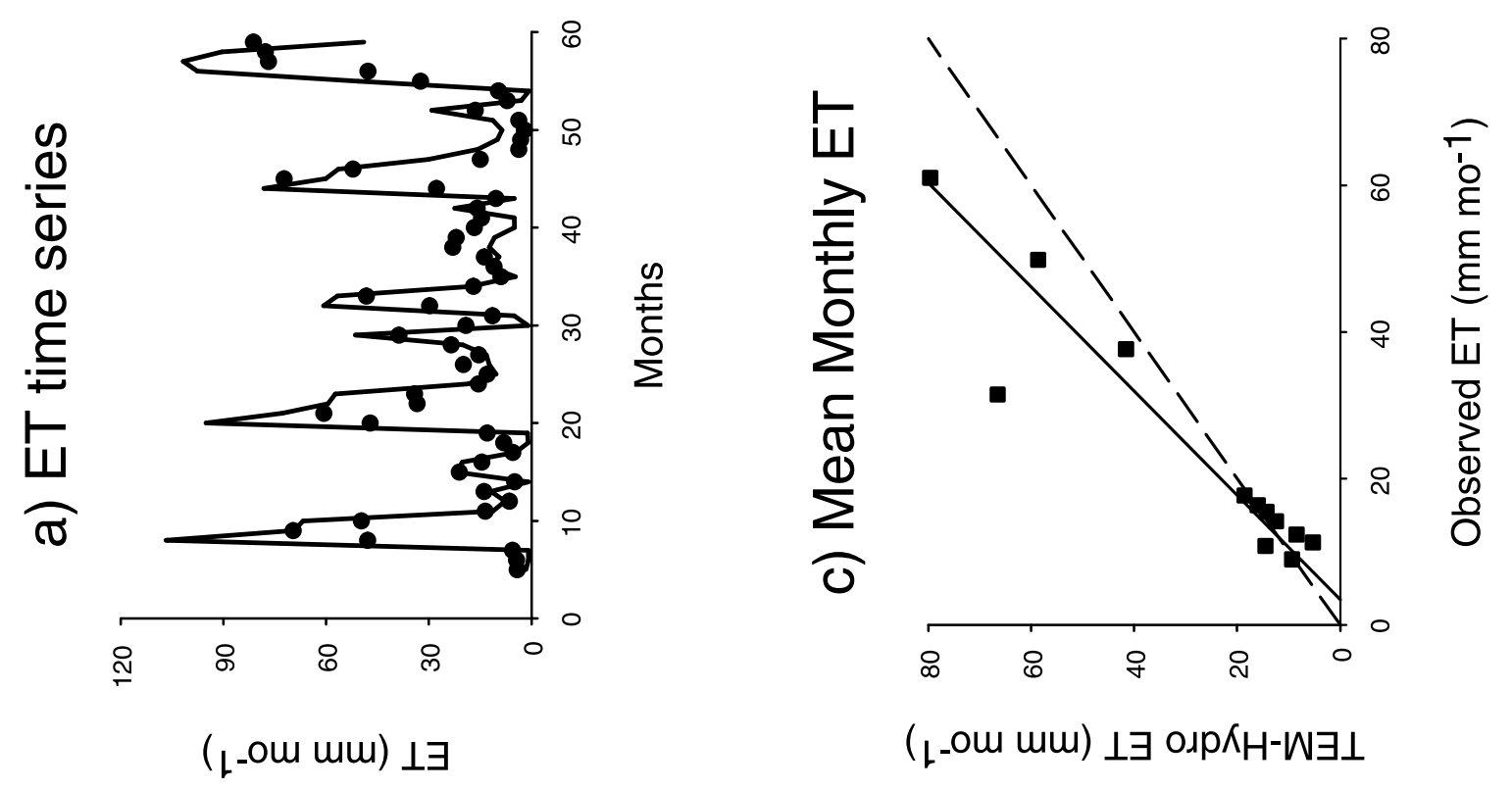

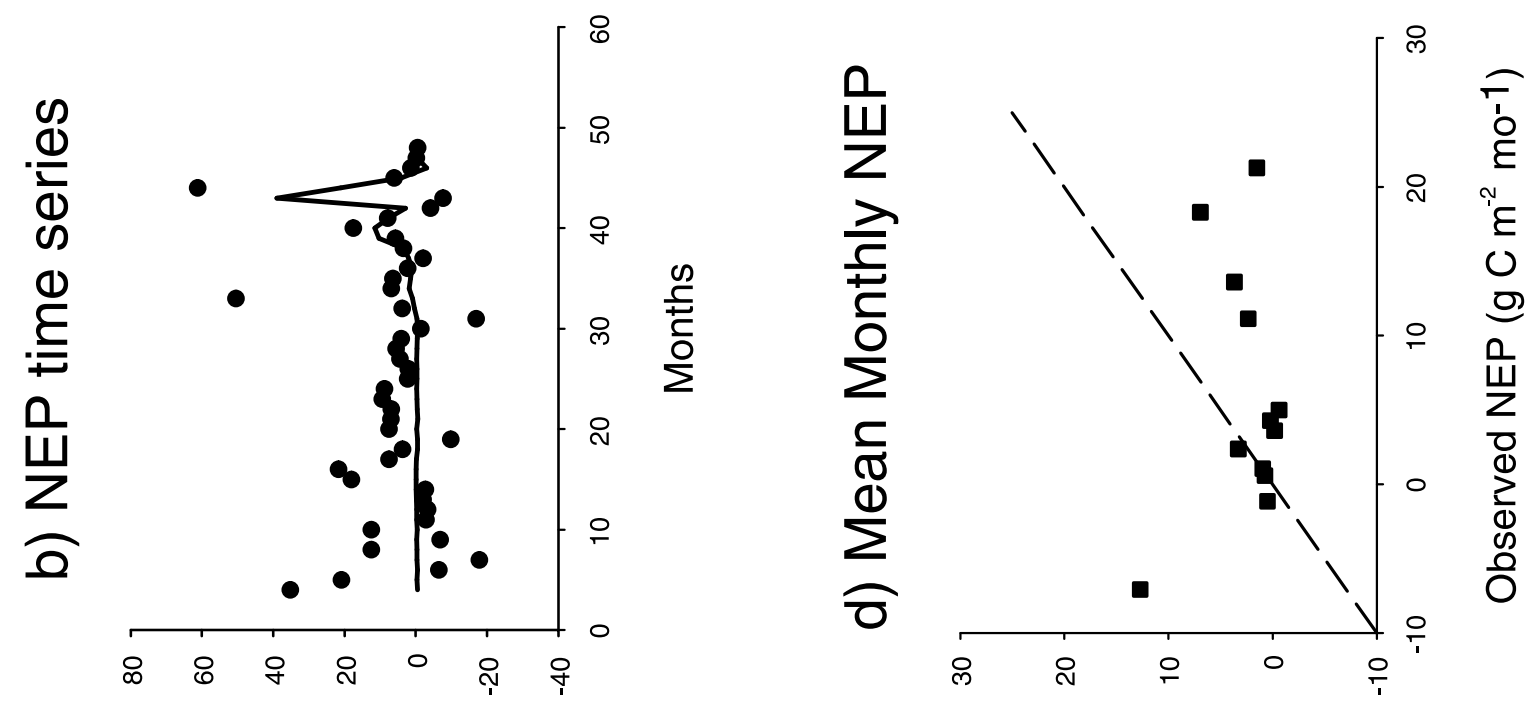

$$
\left({ }^{\prime}-m_{2-} m \rho 6\right) d \exists N
$$

\section{( ᄂ-om z-m o 6) d $\exists N$ oגp $K_{H}-W \exists \perp$}
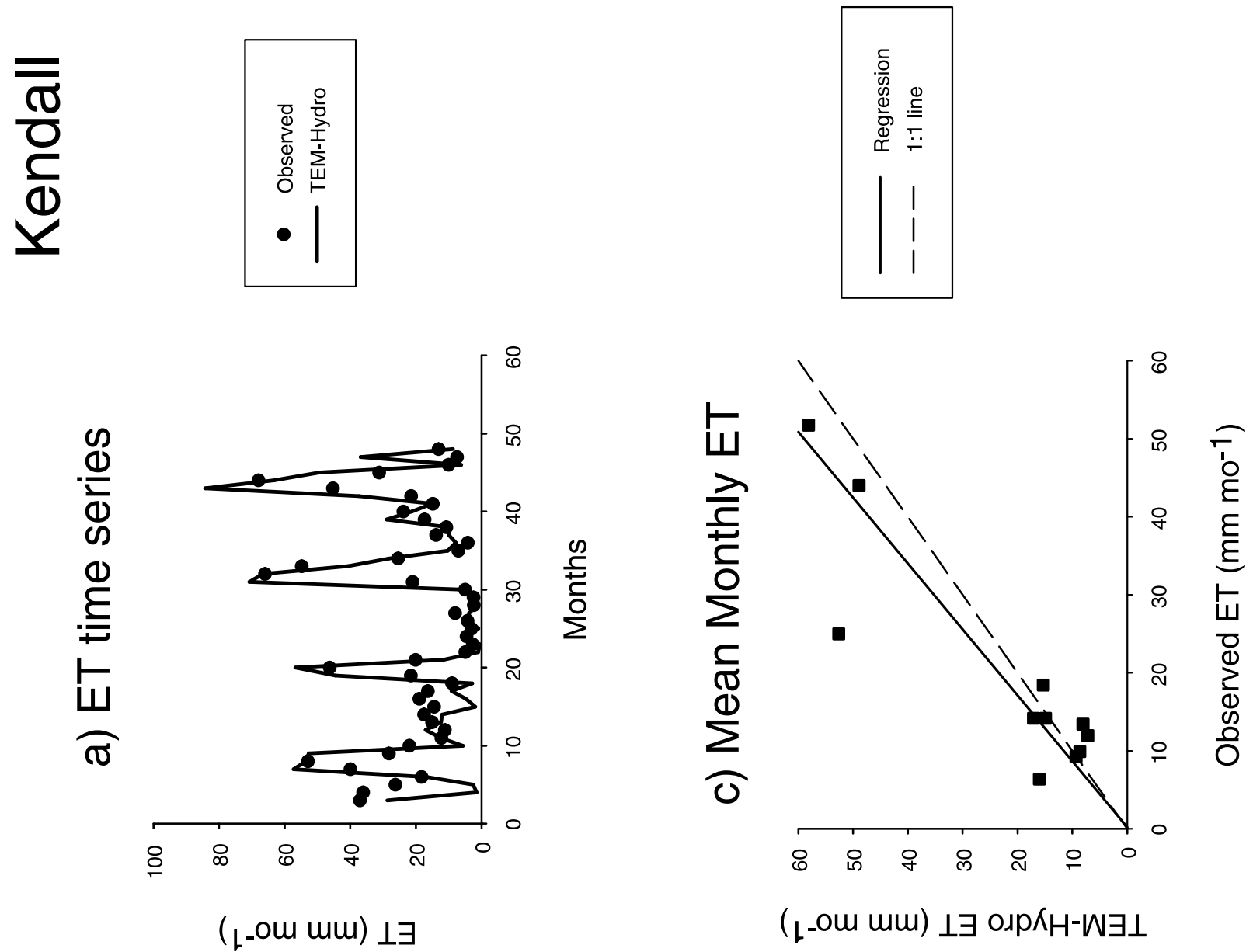
Table 3. Mean Observed and TEM-Hydro ET and NEP With RMS Errors Between Model and Observed Based on Monthly Values

\begin{tabular}{lcccccc}
\hline \multicolumn{1}{c}{ Site } & \multicolumn{1}{c}{ Obs ET } & TEM ET & ET RMS & Obs NEP & TEM NEP NEP RMS \\
\hline Audubon & 24.87 & 30.13 & 18.16 & -3.10 & -0.74 & 32.79 \\
Kendall & 20.69 & 22.19 & 14.87 & 6.08 & 2.06 & 15.17 \\
Fort Peck & 26.53 & 24.01 & 24.67 & -2.59 & -0.23 & 31.75 \\
Tonzi & 34.64 & 32.30 & 19.73 & 12.75 & 1.08 & 68.60 \\
Vaira & 25.02 & 26.63 & 12.41 & 4.46 & -2.39 & 75.44 \\
Blodgett & 45.48 & 13.42 & 29.67 & 60.85 & 45.48 & 68.89 \\
Wind River & 40.50 & 42.34 & 20.18 & 33.87 & 5.47 & 61.88 \\
Metolius & & & & 44.86 & 6.00 & 70.72 \\
\hline
\end{tabular}

Our annual ET and NEP are both underestimated (Figure 10) at Blodget. It has been noted that there is a $12-16 \%$ energy imbalance at this site [Misson et al., 2005], which would mean the eddy covariance ET values are too high. There is also $30 \%$ missing data during the winter, which presumably has been corrected by the gap filling. Misson et al. [2005, 2007] point out the importance of the understory $(24 \%$ shrubs and $18 \%$ grasses, stumps, and bare soil) which we do not account for in TEM. The recovery time since 1990 is also insufficient for TEM to yield a strong carbon sink, as ponderosa pine forests typically take 30 years to achieve positive NEP following disturbance [Campbell et al., 2004]. At Metolius we also underestimate the eddy covariance NEP (Figure 10). We have modeled this site as an old growth forest, though the stand does contain a mixture of 50 and 250 year old trees due to a fire in 1950 [Thornton et al., 2002]. Irvine et al. [2002] show that soil respiration is more related to soil temperature and not moisture, but TEM does not simulate soil temperature separately from air temperature.

[30] In another modeling comparison of these forest sites, Thornton et al. [2002] also underestimated the midsummer NEP peaks. They attributed this bias to too high ecosystem respiration rates. In their case, the modeled ecosystem respiration rates increased too much for high temperatures, especially at Blodget Forest, which points to the need to review the Q10 assumptions. They also modeled much lower NEP values than the eddy covariance measurements at Metolius and Wind River but agreed better with the biometric measurements and argue against large annual sinks at these old sites. It is likely that eddy covariance measurements at these sites are underestimating nighttime respiration. This nighttime bias may result from stagnant nighttime conditions leading to low turbulence [Massman and Lee, 2002] or the effect of sloping terrain on cold air drainage of $\mathrm{CO}_{2}$ to lower terrain [Hanson et al., 2004; Wilson et al., 2002].

[31] Leaf area index (Figure 11) shows that we do well at some sites (Kendall, Fort Peck, Blodget) and overestimate at most of the other sites, except for Wind River. The overestimate is worse at Metolius, where we get more than double the recorded LAI (4.6 versus 2.1). At Wind River, we underestimate the very high LAI of 8.6 by 6.2 . The correlation between measured and modeled LAIs is within $95 \%$ significant.
[32] In addition to site-level comparisons, we also provide a more integrated measure of how well the model compares to observations by evaluating streamflow over watersheds (Figure 12). This comparison enables us to view the model in additional forested basins, as well as shrublands. We have evaluated TEM-Hydro at 18 forested basins (California, Washington, Oregon, Colorado, Idaho, Montana, Nevada), 5 shrubland basins (Arizona, Nevada), and 4 grassland basins (Arizona, Nevada) (Table S4). The basins were chosen to include minimal management, and so were taken from the USGS Hydro-Climatic Data Network (HCDN) [Slack et al., 1993] based on conversations with local USGS water managers in Nevada and Arizona (S. Berris and R. Plume, personal communication, 2010). There are only a limited number of basins with minimal management, especially in lowland areas dominated by shrubs and grasses. In spite of some of the problems at specific forest eddy covariance sites, the runoff over forested basins (Figure 12) is well correlated to observations, with a low bias. The comparison in grassland-dominated basins is also good, with some tendency to overestimate. There is a stronger tendency for the model to overestimate runoff in shrublands, even though we assumed a rooting depth of $5 \mathrm{~m}$. The assumption is consistent with large amounts of phreatophytic shrubs with deep rooting systems and the significant role these plants play in evapotranspiration totals [Canadell et al., 1996; Moreo et al., 2007]. In addition to rooting depth, the Ball et al. [1987] slope and y intercept are particularly important to developing the correct hydrology. Also, in these dry shrub basins, evaporation of surface runoff prior to measurement in streams is an increasingly important process. TEM-Hydro is not capturing this effect, and so an overestimatation of runoff as basins approach the dry limit is more likely.

[33] In light of these comparisons, it is clear that there are several important shortcomings of the TEM-Hydro model. Most important are the single layer of soil, both in terms of decomposition rates, moisture, and temperature and the monthly climatic forcing. Here we have shown ways to get around these problems by providing adjustments for particularly dry conditions. In addition, we have not considered some processes that are occurring in actual eddy covariance environments, such as nitrogen deposition, which could significantly increase the NEE and even affect the seasonality. Ultimately, we may also require separate calibration sites for different types of grasslands and forests, but that requires long-term measurements of carbon stocks and fluxes at representative sites.

\subsection{Overall Effects of Future Climate Change on Terrestrial Carbon and Nitrogen Dynamics}

[34] We model the western landscape as $39 \%$ shrubland, $29 \%$ forest, $23 \%$ grassland, and the remainder as temperate savannas, excluding cropland and deserts (Table 4). Forests are the most productive biome, accounting for twice the GPP and NPP of any other biome. Runoff rates are highest in forests, indicative of the much larger precipitation (Table 1) in

Figure 6. Comparison of temporal patterns (2004-2007) in TEM-Hydro and eddy covariance estimates at the Kendall grassland (Arizona) site for (a) monthly ET and (b) monthly NEP; and comparison of model and observed estimates for (c) monthly ET (m $\left.=1.19, \mathrm{~b}=-0.56, \mathrm{r}^{2}=0.81, \mathrm{p}<0.01\right)$ and (d) monthly NEP. 



( ᄂ-om mu) $\perp \exists$



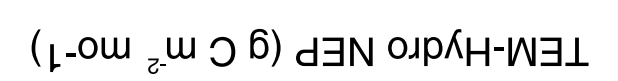



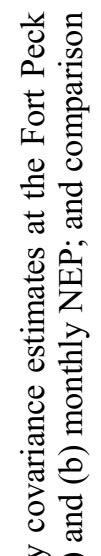

突官

दै $\mathrm{V}$

욘단

象

$\sum_{1}^{2}, \overline{0}$

ni

$\Xi \stackrel{0}{0}$

\&."

ते

00 茫

¿ํ욜 

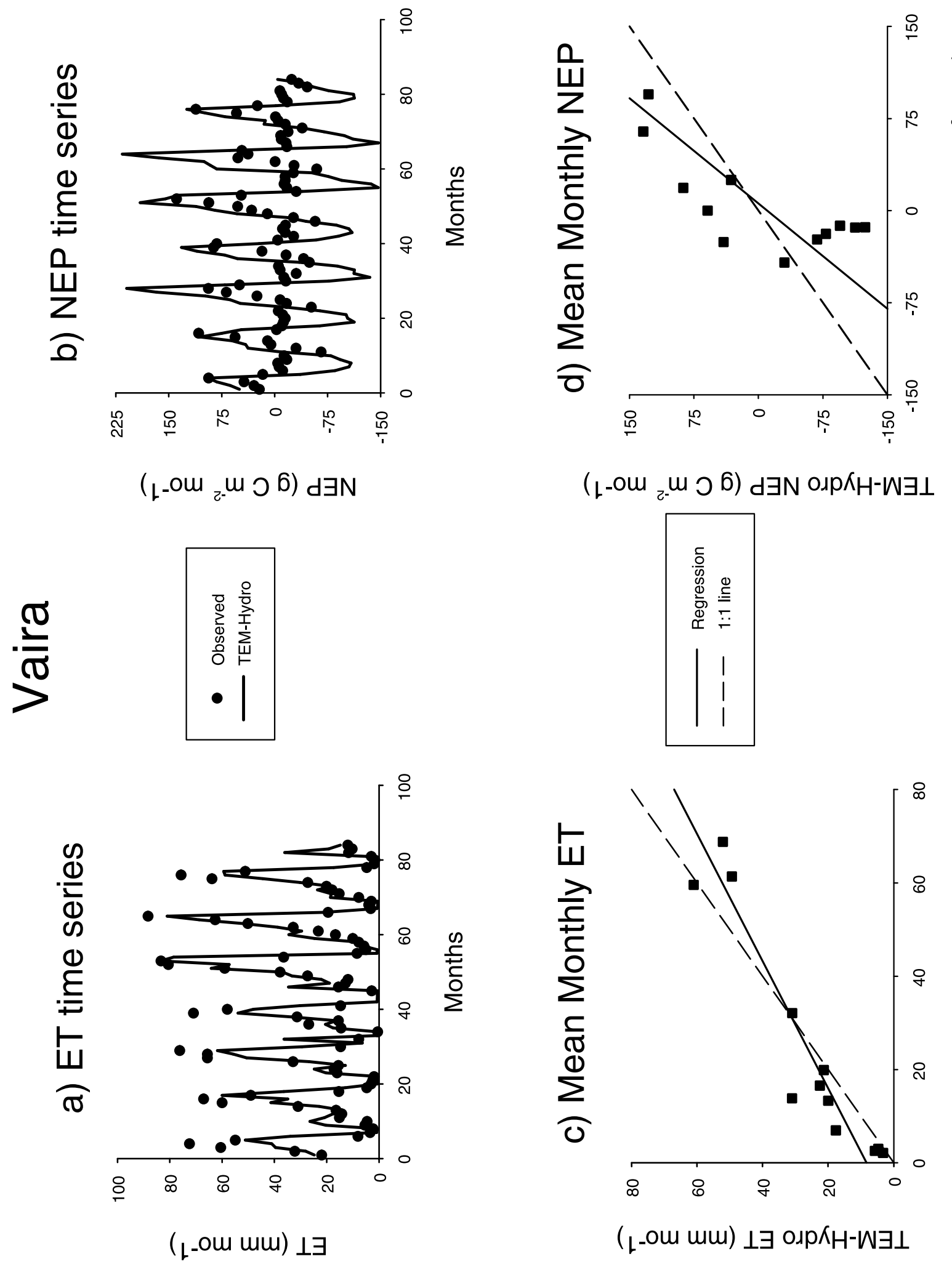

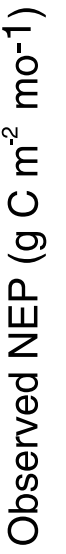

is 11

荡的

( )

이 글

묠

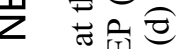

일 믈

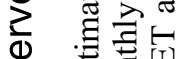

ช 츨

을

측 드

ภ의

궁

엉

를

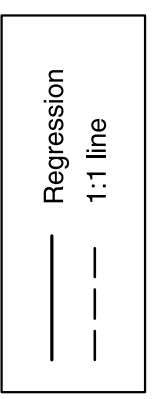

잉

त्र

$\sum^{1} \mathrm{~T}$

in

$\Xi$ 늠

(ิ)

용

तิ

$1 \pi \Xi$

ᄋํㅇ



( 


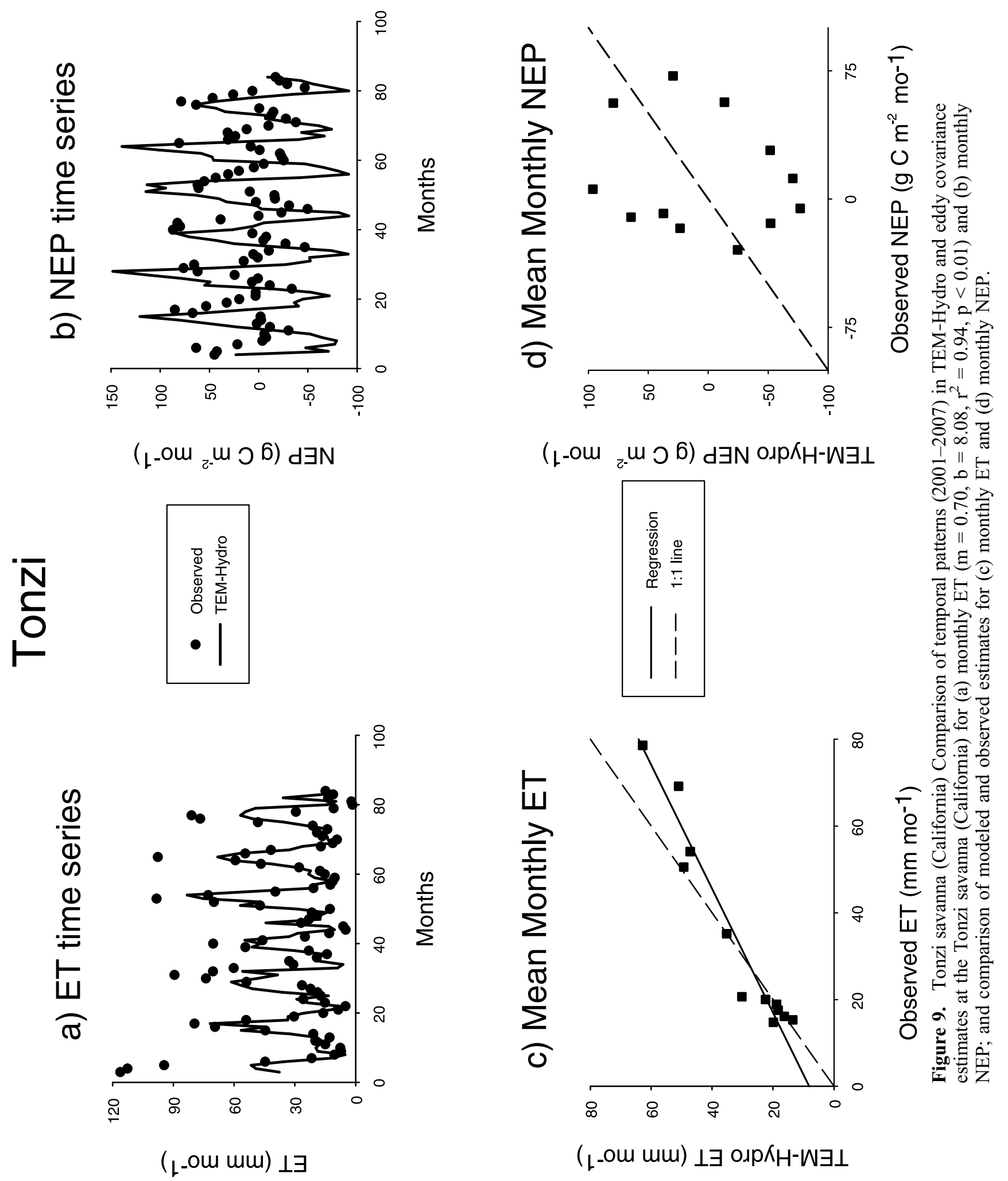



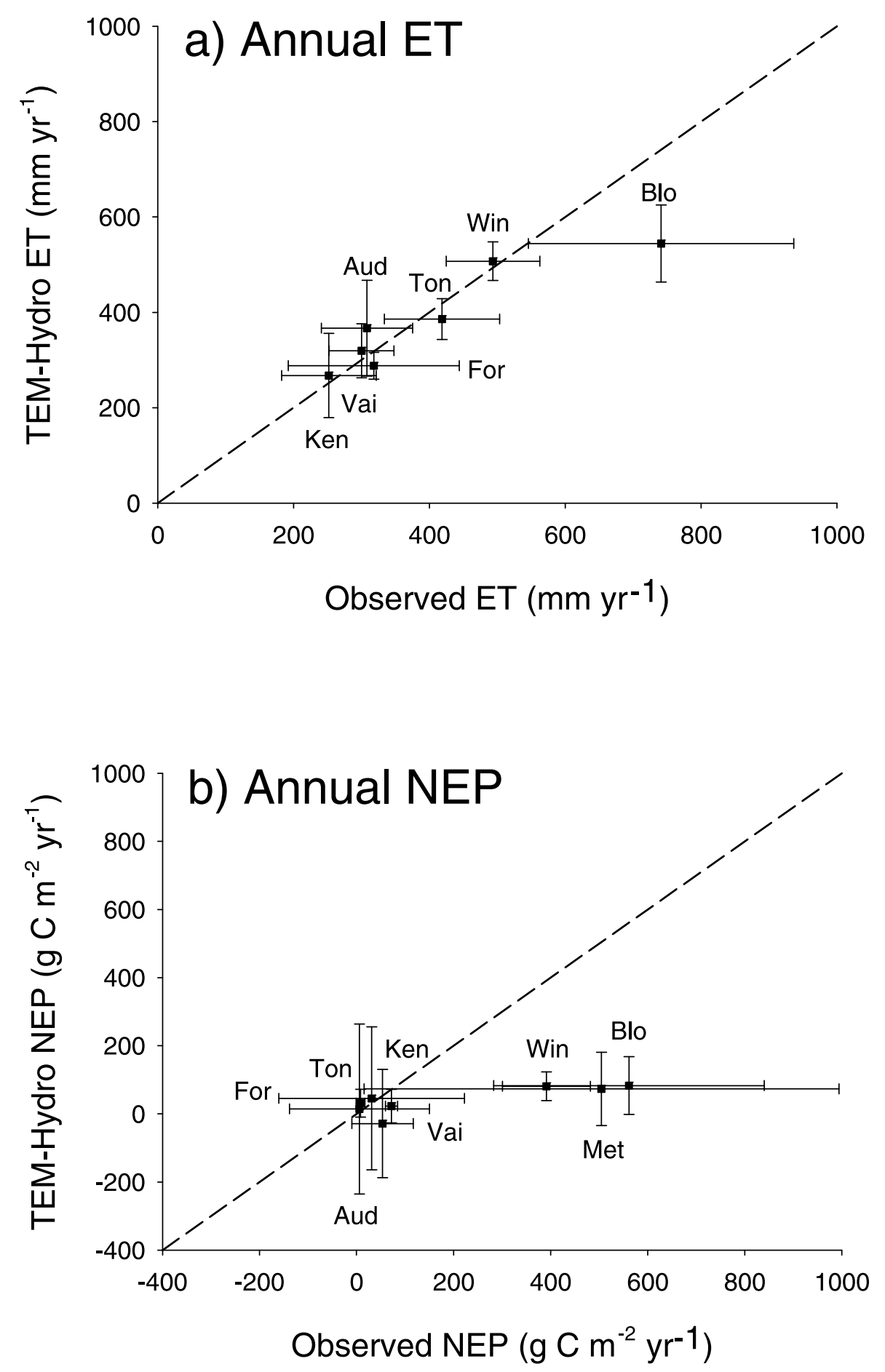

Figure 10. Annual (a) ET $\left(\mathrm{m}=0.58, \mathrm{~b}=149.34, \mathrm{r}^{2}=0.84, \mathrm{p}<0.01\right)$ and (b) NEP $(\mathrm{m}=0.13, \mathrm{~b}=$ $-14.19, r^{2}=0.64, p<0.02$ ) comparison of TEM-Hydro and eddy covariance values averaged over each of the years of eddy covariance data availability. Aud, Audubon; Ken, Kendall; For, Fort Peck; Vai, Vaira; Ton, Tonzi; Win, Wind River; Met, Metolius; Blo, Blodget. ET was not available for Metolius.

forests. However, the amount of water stored in the soils is largest in shrublands (not shown), which is a function of both the lower ET rates and large rooting depth. The ratio of evapotranspiration to precipitation is lowest in forests $(0.28)$, intermediate in grassland (0.4), and highest in shrublands (0.86). The precipitation rates are much higher in forested regions, while in the dryer shrublands, nearly all the precip- itation that fall evaporates. Forests are the most water use efficient of the three biomes. WUE is calculated as the ratio of GPP to transpiration and is a measure of how effectively plants use available water to acquire carbon. Net nitrogen mineralization rates are highest in forests and lowest in shrublands. 


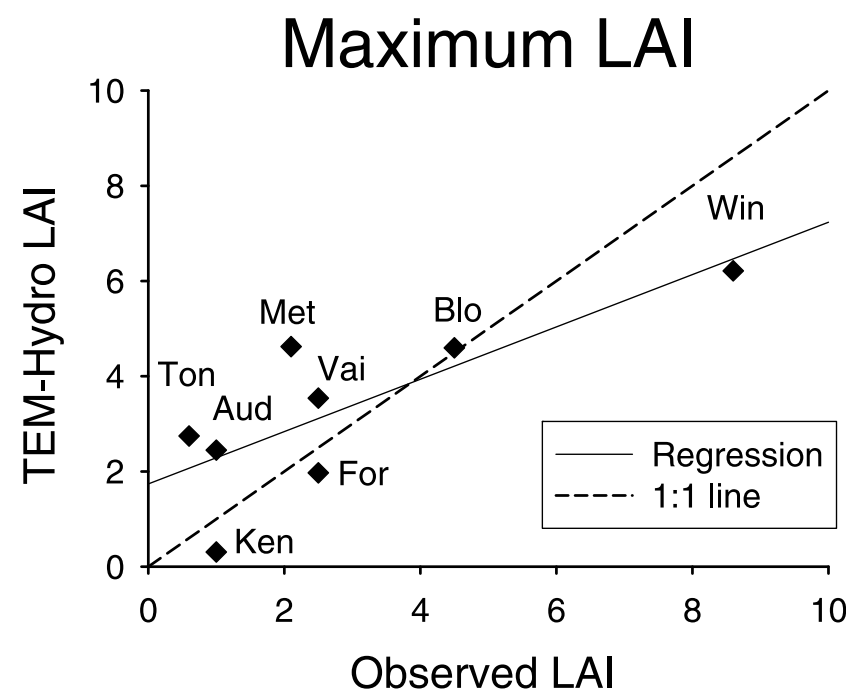

Figure 11. Maximum LAI comparison of TEM-Hydro and measured values for each eddy covariance site $(\mathrm{m}=0.55, \mathrm{~b}=$ $\left.1.74, \mathrm{r}^{2}=0.62, \mathrm{p}<0.05\right)$. Aud, Audubon; Ken, Kendall; For, Fort Peck; Vai, Vaira; Ton, Tonzi; Win, Wind River; Met, Metolius; Blo, Blodget.

[35] Future GPP and NPP increases in the forests but decreases in the shrublands (Table 4). In grasslands, the changes are not significant (Figures 13a and 13b). The ET increases in both forests and grasslands but decreases in shrublands, largely due to the smaller amount of precipitation. Runoff and soil moisture (which follows runoff) decrease in all three biomes but especially in shrublands and grasslands. The respective runoff decreases in forests, shrublands, and grasslands is $22 \%, 67 \%$, and $58 \%$. The WUE increases in all biomes, but especially in forests. Nitrogen mineralization and nitrogen uptake (which follows nitrogen mineralization) increase in all biomes except shrublands (Table 4). To examine the reason for these changes more thoroughly, we next explore the results of our sensitivity studies.

\subsection{Relative Effects of Temperature and Precipitation}

[36] The response of ecosystems to climate itself can be deconstructed into the individual climate components, including temperature, precipitation, clouds, and vapor pressure. While we have done so for each, we only present results for temperature and precipitation as these are the more important factors. For all biomes, climate warming in the West under the A2 scenario leads to reduced GPP and NPP (Figures 13a and 13b). While in forests and shrublands at least half of this reduction is due to lower precipitation, in grasslands the warming itself is responsible for the reduction. Increased ET due to warming in forests and grasslands (Figure 13c) leads to reduced WUE (Figure 13d). The increase in ET from warming is primarily due to the increased vapor pressure deficit and increased PAR (Table 1). Unlike the humid environment of the eastern United States, in the moisture-limited west, extreme warming leads to greater moisture stress which limits vegetation productivity and overcomes any expected benefits. In shrublands, reduced ET results from the more limited water from the reduced precipitation. The increased ET in forests and grasslands, and reduced precipitation in each biome, results in reduced runoff and soil moisture in each biome (Figure 13e). Soil moisture is not shown because the changes in the future are similar to that of runoff. The more arid environment undergoes less nitrogen mineralization (Figure 13f) in each biome. Nitrogen uptake rates also decrease and are not shown because they mirror the response of net $\mathrm{N}$ mineralization. Therefore, increased moisture limitation results in increased nitrogen limitation, which act together to limit the GPP and NPP.

\subsection{Relative Effects of $\mathrm{CO}_{2}$}

[37] Elevated $\mathrm{CO}_{2}$ increased GPP and NPP in forests and shrublands (Figures 13a and 13b) and has little effect in grasslands. The experiment without the effect of $\mathrm{CO}_{2}$ on stomatal conductance illustrates that at least half this increase is due to the indirect effects of $\mathrm{CO}_{2}$ on alleviating moisture stress by reducing stomatal conductance. The remainder is due to direct effects of $\mathrm{CO}_{2}$ fertilization, although that is only significant in forests. $\mathrm{CO}_{2}$ fertilization plays a minor role in shrublands and grasslands due to the prevalence of both nitrogen limitation and the $\mathrm{C} 4$ photosynthetic pathway in these biomes. Elevated $\mathrm{CO}_{2}$ does reduce ET in each biome (Figure 13c), with associated increase in WUE (Figure 13d), which is especially large in forests and shrublands. Without the effect of $\mathrm{CO}_{2}$ on stomatal conductance, sometimes the ET increases and sometimes it decreases. The effect of $\mathrm{CO}_{2}$ on runoff is insignificant (Figure 13e), while it has a strong positive effect on nitrogen mineralization (Figure 13f), and therefore alleviates both moisture and nutrient stresses on plants.

\subsection{Interactive Effects of Climate and $\mathrm{CO}_{2}$}

[38] The increase in GPP and NPP in western forests is much larger for the combined climate and $\mathrm{CO}_{2}$ experiment than for the effects of $\mathrm{CO}_{2}$ alone, even though climate alone reduces GPP and NPP (Figures 13a and 13b). The combined $\mathrm{CO}_{2}+$ climate effect on both WUE (Figure 13d) and nitrogen mineralization (Figure 13f) is positive but not greater than

\section{Mean Annual Runoff}

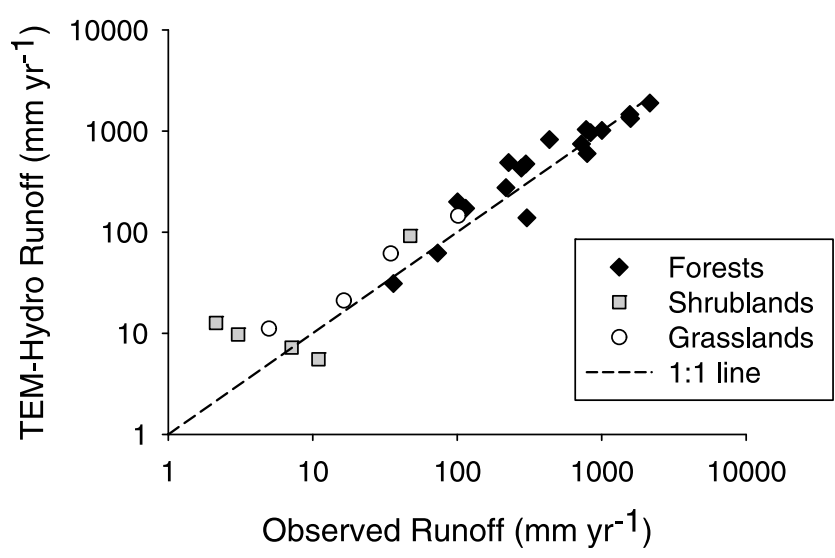

Figure 12. Scatterplot of modeled versus observed runoff for select basins in the western United States (see Table S2). Points above the 1:1 line are model overestimates; points below the 1:1 line are model underestimates. 
Table 4. Estimates of Current and Projected Changes Over the 21 st Century of Gross Primary Production (GPP), Evapotranspiration (ET), Runoff, Water Use Efficiency (WUE), Net Primary Production (NPP), and NetNmin ${ }^{\mathrm{a}}$

\begin{tabular}{|c|c|c|c|c|c|c|c|}
\hline Biome & $\begin{array}{l}\text { Area } \\
\left(\mathrm{km}^{2}\right)\end{array}$ & $\begin{array}{c}\text { GPP } \\
\left(\mathrm{g} \mathrm{C} \mathrm{m}^{-2} \mathrm{yr}^{-1}\right)\end{array}$ & $\frac{\mathrm{ET}}{\left(\mathrm{kg} \mathrm{m}^{-2} \mathrm{yr}^{-1}\right)}$ & $\begin{array}{c}\text { Runoff } \\
\left(\mathrm{kg} \mathrm{m}^{-2} \mathrm{yr}^{-1}\right)\end{array}$ & $\begin{array}{c}\text { WUE } \\
\left(\mathrm{g} \mathrm{C} \mathrm{m}^{-2}\right. \\
\left.\left(\mathrm{kg} \mathrm{H}_{2} \mathrm{O}\right)^{-1}\right)\end{array}$ & $\begin{array}{c}\text { NPP } \\
\left(\mathrm{g} \mathrm{C} \mathrm{m}^{-2} \mathrm{yr}^{-1}\right)\end{array}$ & $\begin{array}{c}\text { NetNmin } \\
\left(\mathrm{mg} \mathrm{N} \mathrm{m}^{-2} \mathrm{yr}^{-1}\right)\end{array}$ \\
\hline \multicolumn{8}{|l|}{ Western forests } \\
\hline Current & 691,473 & 1376 & 422 & 620 & 4.1 & 516 & 6,933 \\
\hline$\Delta$ & & 39 & 11 & -22 & 27 & 32 & 20 \\
\hline \multicolumn{8}{|c|}{ Western shrublands } \\
\hline Current & 936,957 & 244 & 261 & 20 & 3 & 107 & 2,164 \\
\hline$\Delta$ & & -24 & -10 & -67 & -7 & -24 & -24 \\
\hline \multicolumn{8}{|c|}{ Western grasslands } \\
\hline Current & 560,091 & 862 & 305 & 105 & 4 & 243 & 5,324 \\
\hline$\Delta$ & & 10 & 15 & -58 & 7 & -3 & 4 \\
\hline \multicolumn{8}{|c|}{ Total western biomes } \\
\hline Current & $2,390,531$ & 532 & 332 & 221 & 3 & 272 & 4,465 \\
\hline$\Delta$ & & 19 & 3 & -29 & 24 & 13 & 5 \\
\hline
\end{tabular}

${ }^{\mathrm{a}}$ The total western biomes also include temperate savannas.

for $\mathrm{CO}_{2}$ alone. However, when plants are not moisture stressed, warming will increase productivity (to a certain point). By alleviating moisture and nutrient stresses, the warming now has a positive effect on GPP and NPP, resulting in increased productivity. In shrublands these stresses are not overcome by the increased $\mathrm{CO}_{2}$, so the GPP and NPP decrease. There is no significant change in grasslands. Climate warming or more available water both increase heterotrophic respiration $(\mathrm{Rh})$, which increases $\mathrm{N}$ mineralization, but drying will decrease both. Therefore, the combined effect of warming and elevated $\mathrm{CO}_{2}$ on nitrogen mineralization and thereby productivity is a complex interaction of warming and moisture.

\section{Discussion}

[39] The majority of scenarios of future climate for the western United States have projected warmer, drier conditions, particularly in the southwest [Seager et al., 2007; Sheffield and Wood, 2008]. Sheffield and Wood [2008] predicted increases in short-term drought in western North America and increases in long-term drought in central North America using the IPCC AR4 scenarios, with near unanimous agreement on drying in the Southwest.

[40] The effects of warming on nitrogen mineralization and decomposition have been explored in several warming experiments for western biomes. A meta-analysis on different heating methods in tundra, grasslands, and forests [Rustad et al., 2001] concludes that warming results in large increases in soil respiration (20\%), net nitrogen mineralization (46\%), and plant productivity (19\%), with the largest response in forests. Using infrared heat lamps in a Rocky Mountain meadow in Colorado, Harte and Shaw [1995] and Harte et al. [1995] show that with warming, sagebrush and shrubs are favored over forbs as a result of increased soil temperatures and reduced soil moisture.

[41] Other studies confirm the dominant role of soil moisture. Clark [1990] shows that soil moisture is the dominant influence on net $\mathrm{N}$ mineralization rates and species type in an old growth forest in Minnesota. In an upland prairie in Oregon, Pfeifer-Meister and Bridgham [2007] show that soil moisture, not temperature, is the primary factor that determines net $\mathrm{N}$ mineralization rates, with too much soil moisture in winter and too little in summer being the limiting factors. In a tall grass prairie in Nevada, Arnone et al. [2008] found that warming stimulated heterotrophic respiration and suppressed net ecosystem exchange (NEE) by limiting moisture. A study of sagebrush in Wyoming [Burke, 1989] found that nearly all nitrogen mineralization occurs in the spring and early summer when soil moisture levels are sufficient. There may be differences in how soil moisture affects heterotrophic versus autotrophic respiration due to short-term precipitation events that stimulate microbial activity but not root respiration [Baldocchi et al., 2006], but we cannot distinguish these effects at the monthly timescale. The results of our study confirm that warmer temperatures decrease mineralization rates in biomes where moisture limitation is more critical than temperature.

[42] Elevated $\mathrm{CO}_{2}$ increases soil moisture indirectly by reduced evapotranspiration, thereby increasing $\mathrm{N}$ mineralization rates in some biomes (i.e., forests, shrublands). Arnone and Bohlen [1998] studied the effect of elevated $\mathrm{CO}_{2}$ on a Swiss grassland and discovered that increased soil moisture led to more $\mathrm{N}_{2} \mathrm{O}$ flux, heterotrophic respiration, and plant productivity. Changes in GPP will also influence estimates of future evapotranspiration and available water. If GPP is assumed to increase by less than a factor of 2 with a doubling of $\mathrm{CO}_{2}$, then by the Ball et al. [1987] formulation, stomatal conductance will decrease in the future [Medlyn et al., 2001]. The GPP is also linearly dependent on the stomatal conductance due to the net diffusion of $\mathrm{CO}_{2}$ into leaves. So increased $\mathrm{CO}_{2}$ fertilization is offset by the reduced stomatal conductance, but the relative magnitudes of the effects are uncertain [Huang et al., 2007]. Given the feedbacks of stomatal conductance with water and nitrogen and the limited $\mathrm{CO}_{2}$ fertilization due to nitrogen limitation and the presence of $\mathrm{C} 4$ plants, we show only a very small $\mathrm{CO}_{2}$ fertilization effect for grasses and shrubs. However, forests have a significant $\mathrm{CO}_{2}$ fertilization effect. In a modeling study, Piao et al. [2007] counter the results of Gedney et al. [2006] and show that the net effect of increasing $\mathrm{CO}_{2}$ is to increase transpiration due to increases in LAI, which is a structural rather than functional change. Our model does allow for such structural changes, and we 


\section{GPP}
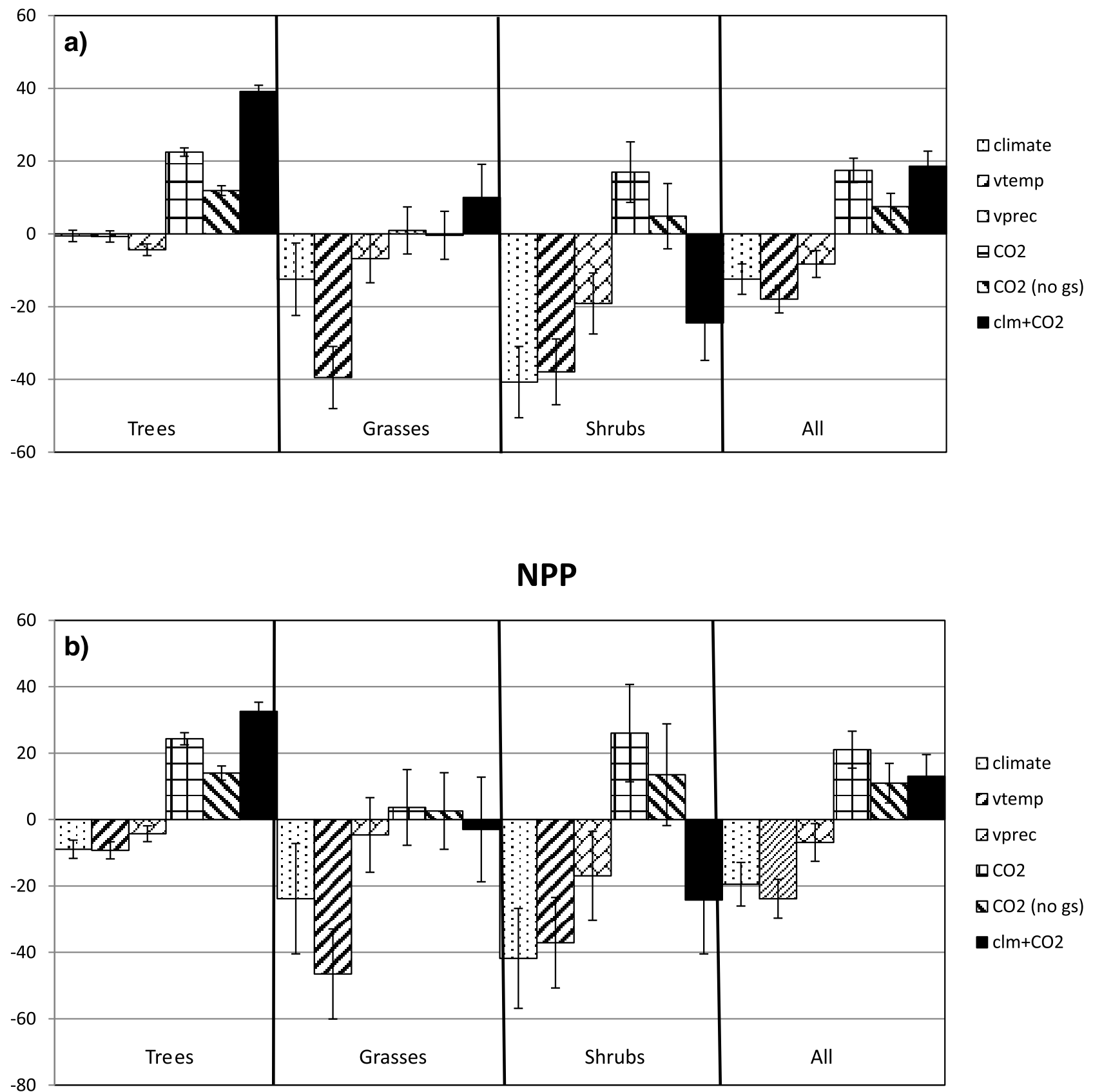

Figure 13. Percent differences between future (2080-2099) and present (1981-2000) for (a) GPP, (b) NPP, (c) ET, (d) WUE, (e) runoff, and (f) net nitrogen mineralization for six sensitivity experiments.

do find a substantial increase in LAI with $\mathrm{CO}_{2}$ only for all biomes, but most of it is driven by the effect of $\mathrm{CO}_{2}$ on stomatal conductance and moisture feedbacks rather than $\mathrm{CO}_{2}$ fertilization itself.

[43] We have found a significant interactive effect between climate warming and elevated $\mathrm{CO}_{2}$ in all biomes, largely arising from increased WUE and alleviation of nitrogen-limiting conditions due to increased nitrogen mineralization rates. Where the warming is not overwhelmed by drying (e.g., forest, grasslands), increased net nitrogen min- eralization results from enhanced microbial decomposition, as confirmed by soil warming experiments [Melillo et al., 2002]. By increasing WUE, elevated $\mathrm{CO}_{2}$ also increases microbial decomposition and hence net nitrogen mineralization in some ecosystems by increasing availability of water in soils. The combined effect of these two processes leads to a large increase (or less of a decrease) in net nitrogen mineralization. This effect is especially prominent in the dry season late in the summer when the effect of $\mathrm{CO}_{2}$ on stomatal conductance alleviates most of the negative effect of the drier 


\section{ET}



WUE

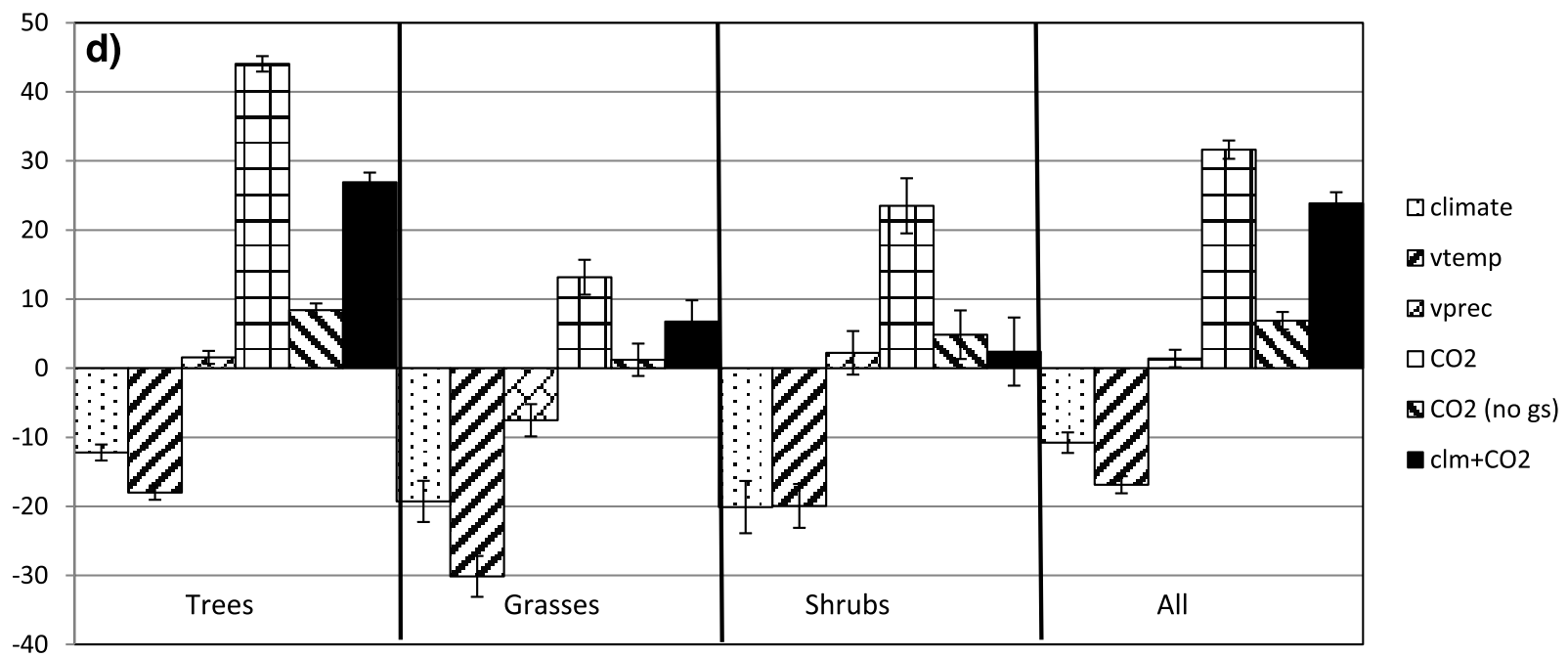

Figure 13. (continued)

climate but combined with the warmer temperature results in an enhanced nitrogen mineralization response. This enhanced nitrogen mineralization along with the increased WUE results in significantly larger GPP levels. This interactive term would only result from modeling studies that include nitrogen and the effects of nitrogen limitation. These results are consistent with the analysis of Norby and Luo [2004], who discuss the possibility of enhanced $\mathrm{CO}_{2}$ fertilization resulting from more nitrogen mineralization.

[44] In the future there will also be changes in vegetation that will alter the landscape and affect the hydrological cycle. Historically, this has already been happening without significant changes in precipitation. Increased mortality rates in western coniferous forests linked to the effects of regional warming, such as reduced snow cover, earlier spring snowmelt and runoff, and summer drought, have been found van Mantgem et al. [2009]. However, the susceptibility of trees to drought stress is highly species dependent and may also be exacerbated by other stresses such as insects [Breshears et al., 2009]. Changes in grassland are often human induced, such as increased woody encroachment into existing grassland due to overgrazing [Archer et al., 1995]. As grazing declines in some regions, such as central Texas, woody encroachment has led to less streamflow due to higher soil infiltration [Wilcox et al., 2008]. These vegetation redistribution effects have not 


\section{Runoff}

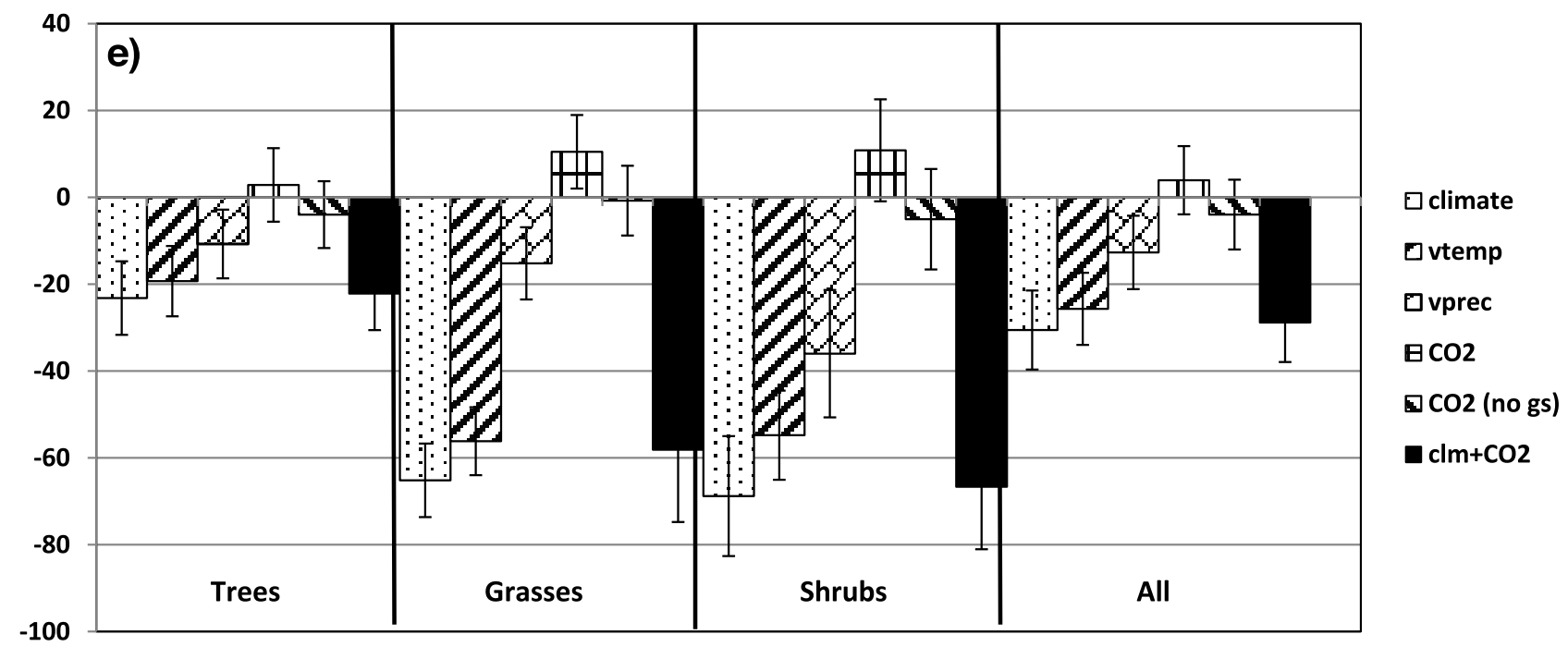

Net Nitrogen Mineralization

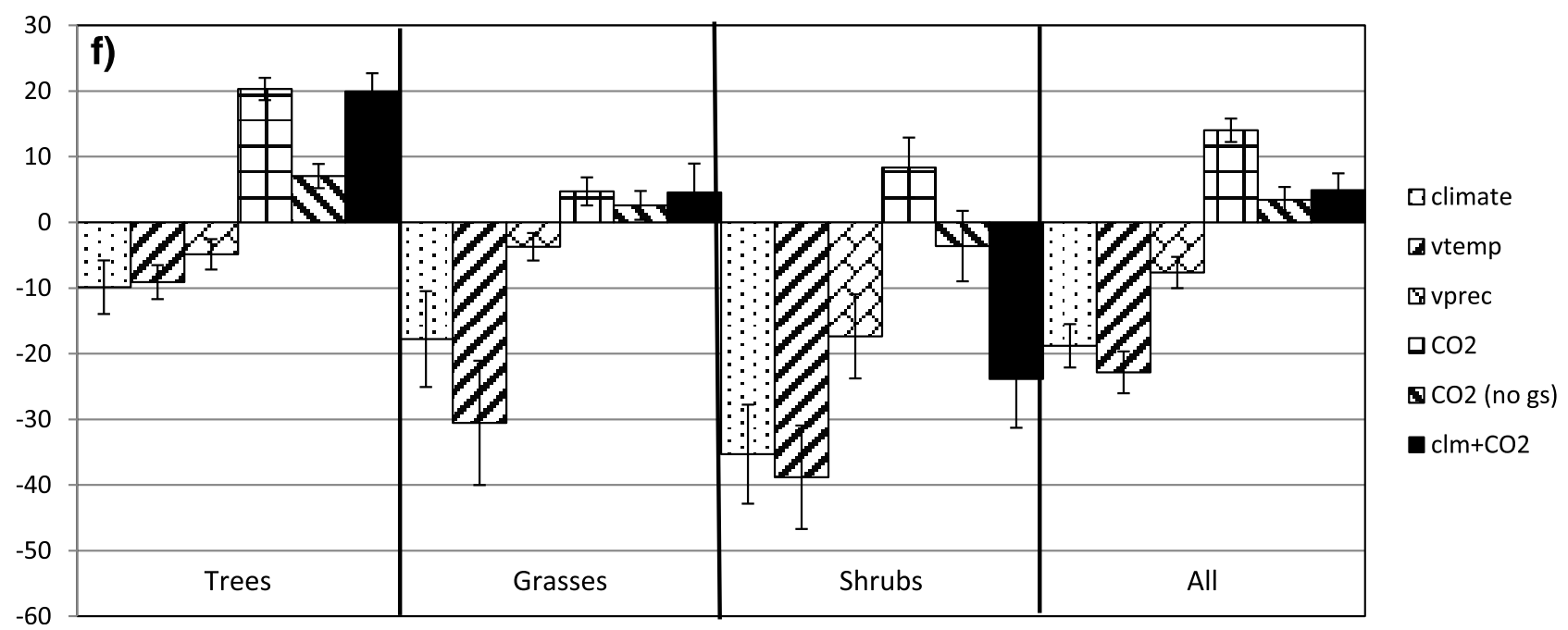

Figure 13. (continued)

been included in our analyses and will need to be modeled accurately in order to produce better ET and runoff estimates for the future.

[45] Future warming may also result in acclimation of leaf respiration [Arnone and Korner, 1997; Gunderson et al., 2000] and photosynthesis [Berry and Bjorkman, 1980; Gunderson et al., 2000]. TEM-Hydro accounts for acclimation in both autotrophic respiration and photosynthesis through use of an optimal temperature that depends on the running mean air temperature. Plant respiration is based on the LaRS [Hanson and Weltzin, 2000] formulation, which allows for acclimation to warmer temperatures. Photosynthesis is maximized at the optimal temperature, decreasing at temperatures both below and above it. This acclimation is highly uncertain and so can affect carbon and water dynamics in the future.
[46] FACE experiments may be used to test our sensitivity to the effects of rising $\mathrm{CO}_{2}$. These experiments are performed with $\mathrm{CO}_{2}$ levels of about $550 \mathrm{ppm}$, which is achieved in the A2 scenario in 1954, so we must take differences between the 2050s and present for comparable changes. For example, stomatal conductance $(g s)$ in forests decreases by $18 \%$ in the $\mathrm{CO}_{2}$-only run, $g s$ for shrubs decreases by $12 \%$, and $g s$ for grasses decreases by $14.5 \%$. These values compare with decreases of $16 \%$ for trees, $12 \%$ for shrubs, and $24 \%$ for $\mathrm{C} 3$ and $\mathrm{C} 4$ grasses for a range of FACE experiments [Ainsworth and Long, 2005], so we are in the correct range for trees and shrubs but too low for grasses.

[47] When comparing forests in the eastern and western United States, a key difference in the A2 scenario is reduced precipitation in the West versus increased precipitation in the East. Compared to the western forests, eastern forests 
have much higher GPP due to moister and generally more fertile conditions, as well as much larger ET and runoff. In our previous experiments in eastern forests, GPP and ET increase as in the western forests, but runoff increases due to more precipitation in the future [Felzer et al., 2009], as well as a much larger $\mathrm{CO}_{2}$ effect on stomatal conductance resulting from less $\mathrm{CO}_{2}$ fertilization in the more humid climate. By comparison, our new experiments show that the increase in GPP in the eastern forests is also a result of nonlinear combinations of the individual climate components, while ET increases and runoff decreases are similarly constrained by warming. While reduced precipitation decreases nitrogen mineralization in the West, increased precipitation increases nitrogen mineralization in the east.

\section{Conclusions}

[48] In this modeling study we examine the relative importance of climate change and elevated $\mathrm{CO}_{2}$ on the carbon and water dynamics of the arid west and how they are affected by nitrogen and moisture limiting conditions. The effects of climate changes are partitioned into temperature and precipitation, while the effects of $\mathrm{CO}_{2}$ are partitioned between $\mathrm{CO}_{2}$ fertilization and stomatal conductance. We use downscaled climate output from the NCAR CCSM3 A2 scenario and AVHRR-based land cover to force the TEM model and generate detailed vegetation and soil biogeochemistry. This scenario results in warmer and drier conditions for the West. We show that carbon-nitrogenwater interactions and feedbacks are crucial to determining future vegetation productivity and water availability.

[49] The GPP and NPP ultimately tend to track with nitrogen mineralization in these nitrogen-limited biomes. A consequence of warming is to increase decomposition and thereby increase net nitrogen mineralization, creating more inorganic nitrogen for plant uptake. However, we show that warming by itself does not increase nitrogen mineralization rates in the western United States in especially dry biomes like shrublands because the warming causes more drying and moisture limitation, which then limits nitrogen mineralization rates. Reduced precipitation also decreases nitrogen mineralization rates throughout the West. Elevated $\mathrm{CO}_{2}$ increases nitrogen mineralization rates because of the increased water use efficiency and resulting soil moisture, especially in forests. In shrublands, the environment is so moisture limited that elevated $\mathrm{CO}_{2}$ does not compensate and nitrogen mineralization rates decrease. Thus, moisture is the ultimate limiting variable in these western ecosystems, but it is the effect of moisture on nitrogen, and how that compensates for warming itself, that may hold the key to future productivity.

[50] These effects of water on nitrogen result in increased NPP in forests $(33 \%)$, but decreased NPP in shrublands (24\%). Runoff decreases in all western biomes, by $29 \%$ overall. Every variable results in less runoff except the effects of elevated $\mathrm{CO}_{2}$ on stomatal conductance but does not compensate for the drying effects of climate change. Warmer temperatures are more important to reduced future runoff than the reduced precipitation itself. $\mathrm{CO}_{2}$ fertilization effects are only significant in forests because of nitrogen limiting conditions and also the prevalence of $\mathrm{C} 4$ grasses and shrubs.
[51] Future studies ought to therefore consider $\mathrm{C}-\mathrm{N}$ interactions within the context of moisture-limiting conditions created by future warming. While elevated $\mathrm{CO}_{2}$ has been noted to reduce stomatal conductance and transpiration and thereby increase runoff, that has the effect of stimulating nitrogen mineralization to promote plant growth. These complex feedbacks produce a nonlinear response between climate warming and elevated $\mathrm{CO}_{2}$ that results in more productivity than might otherwise be the case. Runoff itself is more directly a linear response of climate and $\mathrm{CO}_{2}$ effects. All of these processes are occurring whether or not precipitation is increasing or decreasing. As more fully coupled Earth system models are now beginning to incorporate the effects of $\mathrm{C}-\mathrm{N}$ dynamics, it will be interesting to explore these feedbacks within the context the coupled land atmosphere system. The relation between evapotranspiration and runoff is complicated by the issue of precipitation recycling [Eltahir and Bras, 1996], which can only be addressed with coupled land-atmosphere models.

[52] Acknowledgments. This study was funded by the Department of Energy, Basic Research and Modeling to Support Integrated Assessment, DE-FG02-08ERG64648. We acknowledge the modeling groups, the Program for Climate Model Diagnosis and Intercomparison (PCMDI) and the WCRP's Working Group on Coupled Modeling (WGCM) for their roles in making available the WCRP CMIP3 multimodel data set. Support of this data set is provided by the Office of Science, U.S. Department of Energy. We also acknowledge the Global Land Cover Facility data set. We would like to thank Dork Sahagian and Eungul Lee for providing valuable suggestions and insights and S. Bandyopadhyay for his advice on the statistical analysis.

\section{References}

Ainsworth, E. A., and S. P. Long (2005), What have we learned from 15 years of free-air $\mathrm{CO} 2$ enrichment (FACE)? A meta-analytic review of the responses of photosynthesis, canopy properties and plant production to rising $\mathrm{CO}_{2}$, New Phytol., 165(2), 351-372, doi:10.1111/j.14698137.2004.01224.x.

Alexander, M. (1977), Introduction to Soil Microbiology, 2nd ed., John Wiley, New York, New York.

Allison, I., et al. (2009), The Copenhagen diagnosis: Updating the world on the latest climate science, report, 60 pp., Univ. of New South Wales Clim. Change Res. Cent., Sydney, Australia.

Archer, S., D. S. Schimel, and E. A. Holland (1995), Mechanisms of shrubland expansion: Land use, climate, or $\mathrm{CO}_{2}$ ? Clim. Change, 29, 91-99, doi:10.1007/BF01091640.

Arnone, J. A., III, and P. J. Bohlen (1998), Stimulated $\mathrm{N}_{2} \mathrm{O}$ flux from intact grassland monliths after two growing seasons under elevated atmospheric $\mathrm{CO}_{2}$, Oecologia, 116, 331-335, doi:10.1007/s004420050594.

Arnone, J. A., III, and C. Korner (1997), Temperature adaptation and acclimation potential of leaf dark respiration in two species of Ranunculus from warm and cold habitats, Arct. Alp. Res., 29(1), 122-125, doi:10.2307/1551842.

Arnone, J. A. I., et al. (2008), Prolonged suppression of ecosystem carbon dioxide uptake after an anomalously warm year, Nature, 455, 383-386, doi:10.1038/nature07296.

Baldocchi, D., J. Tang, and L. Xu (2006), How switches and lages in biophysical regulators affect spatial-temporal variation of soil respiration in an oak-grass savanna, J. Geophys. Res., 111, G02008, doi:10.1029/ 2005JG000063.

Ball, J. T., I. E. Woodrow, and J. A. Berry (1987), A model predicting stomatal conductance and its contribution to the control of photosynthesis under different environmental conditions, in Progress in photosynthesis research: Proceedings of the VIIth International Congress on Photosynthesis, Providence, Rhode Island, USA, August 10-15, 1986, vol. 4, edited by J. Biggens, pp. 221-224, Martinus Nijhoff, Dordrecht, Netherlands.

Berry, J., and O. Bjorkman (1980), Photosynthetic response and adaptation to temperature in higher plants, Annu. Rev. Plant Physiol., 31, 491-543, doi:10.1146/annurev.pp.31.060180.002423. 
Betts, R. A., et al. (2007), Projected increase in continental runoff due to plant responses to increasing carbon dioxide, Nature, 448, 1037-1041, doi:10.1038/nature06045

Breshears, D. D., O. B. Myers, C. W. Meyer, F. J. Barnes, C. B. Zou, C. D Allen, N. G. McDowell, and W. T. Pockman (2009), Tree die-off in response to global change-type drought: Mortality insights from a decade of plant water potential measurements, Front. Ecol. Environ, 7(4), 185-189, doi:10.1890/080016.

Burke, I. C. (1989), Control of nitrogen mineralization in a sagebrush steppe landscape, Ecology, 70(4), 1115-1126, doi:10.2307/1941380.

Campbell, J. L., O. J. Sun, and B. E. Law (2004), Disturbance and net ecosystem production across three climatically distinct forest landscapes, Global Biogeochem. Cycles, 18, GB4017, doi:10.1029/2004GB002236.

Canadell, J., R. B. Jackson, J. R. Ehleringer, H. A. Mooney, O. E. Sala, and E. D. Schulze (1996), Maximum rooting depth of vegetation types at the global scale, Oecologia, 108, 583-595, doi:10.1007/BF00329030.

Clark, F. E. (1967), Bacteria in soil, in Soil Biology, edited by A. Burges and F. Raw, pp. 15-49, Academic, London.

Clark, J. S. (1990), Landscape interactions among nitrogen mineralization, species composition, and long-term fire frequency, Biogeochemistry, 11, 1-22, doi:10.1007/BF00000849.

Collins, W. D., et al. (2006), The Community Climate System Mode Version 3(CCSM3), J. Clim., 19, 2122-2143, doi:10.1175/JCLI3761.1.

Cook, E. R., C. A. Woodhouse, C. M. Eakin, D. M. Meko, and D. W. Stahle (2004), Long-term aridity changes in the western United States, Science, 306, 1015-1018, doi:10.1126/science.1102586.

Curtis, P. S., and X. Wang (1998), A meta-analysis of elevated $\mathrm{CO}_{2}$ effects on woody plant mass, form, and physiology, Oecologia, 113, 299-313, doi:10.1007/s004420050381.

Daly, C., R. P. Neilson, and D. L. Phillips (1994), A statistical-topographic model for mapping climatological precipitation over mountainous terrain, J. Appl. Meteorol., 33, 140-158, doi:10.1175/1520-0450(1994) $033<0140$ :ASTMFM $>2.0 . \mathrm{CO} ; 2$

DeFries, R., C. Hansen, J. R. G. Townshend, A. C. Janetos, and T. R. Loveland (2000), A new global 1-km dataset of percentage tree cover derived from remote sensing, Global Change Biol., 6, 247-254, doi:10.1046/ j.1365-2486.2000.00296.x.

Domingo, F., L. Villagarcia, A. J. Brenner, and J. Puigdefabregas (1999), Evapotranspiration model for semi-arid shrub-lands tested against data from SE Spain, Agric. For. Meteorol., 95, 67-84, doi:10.1016/S01681923(99)00031-3.

Eltahir, E. A. B., and R. L. Bras (1996), Precipitation recycling, Rev. Geophys., 34(3), 367-378, doi:10.1029/96RG01927.

Falk, M., S. Wharton, M. Schroeder, S. Ustin, and K. T. Paw U (2008), Flux partitioning in an old-growth forest: Seasonal and interannual dynamics, Tree Physiol., 28, 509-520.

Federer, C. A., C. J. Vörösmarty, and B. Fekete (1996), Intercomparison of methods for calculating potential evapotranspiration in regional globa water balance models, Water Resour. Res., 32, 2315-2321, doi:10.1029/96WR00801.

Felzer, B. S. F., D. W. Kicklighter, J. M. Melillo, C. Wang, Q. Zhuang, and R. G. Prinn (2004), Ozone effects on net primary production and carbon sequestration in the conterminous United States using a biogeochemistry model, Tellus, Ser. B, 56, 230-248, doi:10.1111/j.16000889.2004.00097.x

Felzer, B. S., T. W. Cronin, J. M. Reilly, J. M. Melillo, and X. Wang (2007), Impacts of ozone on trees and crops, C. R. Geosci., 339, 784-798, doi:10.1016/j.crte.2007.08.008

Felzer, B. S., T. W. Cronin, J. M. Melillo, D. W. Kicklighter, and C. A Schlosser (2009), Importance of carbon-nitrogen interactions and ozone on ecosystem hydrology during the 21 st century, J. Geophys. Res., 114 G01020, doi:10.1029/2008JG000826.

Fenn, M. E., et al. (2003), Ecological effects of nitrogen deposition in the western United States, BioScience, 53(4), 404-420, doi:10.1641/00063568(2003)053[0404:EEONDI]2.0.CO;2.

Field, C. B., and J. Kaduk (2004), The carbon balance of an old-growth forest: Building across approaches, Ecosystems, 7, 525-533, doi:10.1007/s10021-004-0142-7.

Finzi, A. C., et al. (2006), Progressive nitrogen limitation of ecosystem processes under elevated $\mathrm{CO} 2$ in a warm-temperate forest, Ecology, 87(1), 15-25, doi:10.1890/04-1748.

Gedney, N., P. M. Cox, R. A. Betts, O. Boucher, C. Huntingford, and P. A Stott (2006), Detection of a direct carbon dioxide effect in continental river runoff records, Nature, 439, 835-838, doi:10.1038/nature04504.

Gunderson, C. A., and S. D. Wullschleger (1994), Photosynthetic acclimation in trees to rising atmospheric $\mathrm{CO}_{2}$ : A broader perspective, Photosynth. Res., 39, 369-388, doi:10.1007/BF00014592.

Gunderson, C. A., R. J. Norby, and S. D. Wullschleger (2000), Acclimation of photosynthesis and respiration to simulated climatic warming in north- ern and southern populations of Acer saccharum: Laboratory and field evidence, Tree Physiol., 20, 87-96.

Hansen, M., R. DeFries, J. R. G. Townsend, and R. Sohlberg (2000), Global land cover classification at $1 \mathrm{~km}$ resolution using a decision tree classifier, Int. J. Remote Sens., 21, 1331-1364, doi:10.1080/ 014311600210209

Hanson, P. J., and J. F. Weltzin (2000), Drought disturbance from climate change: Response of United States forests, Sci. Total Environ., 262(3), 205-220, doi:10.1016/S0048-9697(00)00523-4.

Hanson, P. J., et al. (2004), Oak forest carbon and water simulations: Model intercomparisons and evaluations against independent data, Ecol. Monogr., 74(3), 443-489, doi:10.1890/03-4049.

Harmon, M. E., K. Bible, M. G. Ryan, D. C. Shaw, H. Chen, J. Klopatek, and X. Li (2004), Production, respiration, and overall carbon balance in an old-growth Pseudotsuga-Tsuga forest ecosystem, Ecosystems, 7, 498-512.

Harte, J., and R. Shaw (1995), Shifting dominance within a montane vegetation community: Results of a climate-warming experiment, Science, 267, 876-880, doi:10.1126/science.267.5199.876.

Harte, J., M. S. Torn, F. Chang, B. Feifarek, A. P. Kinzig, R. Shaw, and K. Shen (1995), Global warming and soil microclimate: Results from a meadow-warming experiment, Ecol. Appl., 5(1), 132-150, doi:10.2307/ 1942058 .

Huang, J., Y. Bergeron, B. Denneler, F. Berninger, and J. Tardif (2007) Response of forest trees to increased atmosphere CO2, Crit. Rev. Plant Sci., 26, 265-283, doi:10.1080/07352680701626978.

Intergovernmental Panel on Climate Change (IPCC) (2007), Climate Change 2007: The Physical Science Basis: Working Group I Contribution to the Fourth Assessment Report of the IPCC, edited by S. Solomon et al., Cambridge Univ. Press, New York.

Irvine, J., B. E. Law, P. M. Anthoni, and F. C. Meinzer (2002), Water limitations to carbon exchange in old-growth and young ponderosa pine stands, Tree Physiol., 22, 189-196.

Kimball, B. A. (1983), Carbon dioxide and agricultural yield: An assemblage and analysis of 430 prior observations, Agron. J., 75, 779-788, doi:10.2134/agronj1983.00021962007500050014x.

Krakauer, N. Y., and I. Fung (2008), Mapping and attribution of change in streamflow in the coterminous United States, Hydrol. Earth Syst. Sci., 12 , 1111-1120, doi:10.5194/hess-12-1111-2008.

Krishnan, P., T. P. Meyers, and M. M. Heuer (2008), Changes in the energy, water vapour and $\mathrm{CO}_{2}$ fluxes over a semi-arid grassland after fire disturbance, Eos Trans. $A G U, 89(53)$, Fall Meet. Suppl., Abstract B31D-0330.

Luo, Y. Q., et al. (2004), Progressive nitrogen limitation of ecosystem responses to rising atmospheric carbon dioxide, BioScience, 54 , 731-739, doi:10.1641/0006-3568(2004)054[0731:PNLOER]2.0.CO;2.

Magnani, F., et al. (2007), The human footprint in the carbon cycle of temperate and boreal forests, Nature, 447, 849-851, doi:10.1038/ nature 05847 .

Massman, W. J., and X. Lee (2002), Eddy covariance flux corrections and uncertainties in long-term studies of carbon and energy exchanges, Agric. For. Meteorol., 113, 121-144, doi:10.1016/S0168-1923(02)00105-3.

Maurer, E. P., L. Brekke, T. Pruitt, and P. B. Duffy (2007), Fine-resolution climate projections enhance regional climate change impact studies, Eos Trans. $A G U, 88(47)$, 504, doi:10.1029/2007EO470006.

McGuire, A. D., J. M. Melillo, D. W. Kicklighter, Y. Pan, X. Xiao, J. Helfrich, B. Moore III, C. J. Vörösmarty, and A. L. Schloss (1997), Equilibrium responses of global net primary production and carbon storage to doubled atmospheric carbon dioxide: Sensitivity to changes in vegetation nitrogen concentration, Global Biogeochem. Cycles, 11, 173-189, doi:10.1029/97GB00059.

Medlyn, B. E., et al. (2001), Stomatal conductance of forest species after long-term exposure to elevated $\mathrm{CO}_{2}$ concentration: A synthesis, New Phytol., 149, 247-264, doi:10.1046/j.1469-8137.2001.00028.x.

Melillo, J. M., P. A. Steudler, J. D. Aber, K. Newkirk, H. Lux, F. P. Bowles, C. Catricala, A. Magill, T. Ahrens, and S. Morrisseau (2002), Soil warming and carbon-cycle feedbacks to the climate system, Science, 298, 2173-2176, doi:10.1126/science.1074153.

Melillo, J. M., et al. (2011), Soil warming, Carbon-nitrogen interactions and forest carbon budgets, Proc. Natl. Acad. Sci. U. S. A., doi:10.1073/pnas.1018189108, in press.

Miller, G. R., X. Chen, Y. Rubin, S. Ma, and D. D. Baldocchi (2010), Groundwater uptake by woody vegetation in a semiarid oak savanna, Water Resour. Res., 46, W10503, doi:10.1029/2009WR008902.

Misson, L., J. Tang, M. Xu, M. McKay, and A. Goldstein (2005), Influences of recovery from clear-cut, climate variability, and thinning on the carbon balance of a young ponderosa pine plantation, Agric. For. Meteorol., 130, 207-222, doi:10.1016/j.agrformet.2005.04.001.

Misson, L., et al. (2007), Partitioning forest carbon fluxes with overstory and understory eddy-covariance measurements: A synthesis based on 
FLUXNET data, Agric. For. Meteorol., 144, 14-31, doi:10.1016/j. agrformet.2007.01.006.

Mitchell, T. D., T. R. Carter, P. D. Jones, M. Hulme, and M. New (2004) A comprehensive set of high-resolution grids of monthly climate for Europe and the globe: The observed record (1901-2000) and 16 scenarios (2001-2100), Tyndall Cent. Working Pap. 55, Tyndall Cent. for Clim. Change Res., Norwich, U. K.

Moreo, M. T., R. J. Laczniak, and D. I. Stannard (2007), Evapotranspiration rate measurements of vegetation typical of ground-water discharge areas in the Basin and Range carbonate-rock aquifer system, White Pine County, Nevada and adjacent areas in Nevada and Utah, September 2005-August 2006, U.S. Geol. Surv. Sci. Invest. Rep., 2007-5078, 36 pp.

Norby, R. J., and Y. Luo (2004), Evaluating ecosystem responses to rising atmospheric $\mathrm{CO}_{2}$ and global warming in a multi-factor world, New Phytol., 162, 281-293, doi:10.1111/j.1469-8137.2004.01047.x.

Norby, R. J., S. D. Wullschleger, C. A. Gunderson, D. W. Johnson, and R. Ceulemans (1999), Tree responses to rising $\mathrm{CO}_{2}$ in field experiments: Implications for the future forest, Plant Cell Environ., 22, 683-714, doi:10.1046/j.1365-3040.1999.00391.x.

Norby, R. J., et al. (2005), Forest response to elevated $\mathrm{CO}_{2}$ is conserved across a broad range of productivity, Proc. Natl. Acad. Sci. U. S. A., 102(50), 18,052-18,056, doi:10.1073/pnas.0509478102.

Pataki, D. E., T. E. Huxman, D. N. Jordan, S. F. Zitzer, S. Coleman, S. D. Smith, R. S. Nowak, and R. Seemann (2000), Water use of two Mojave Desert shrubs under elevated CO2, Global Change Biol., 6, 889-897, doi:10.1046/j.1365-2486.2000.00360.x.

Pfeifer-Meister, L., and S. D. Bridgham (2007), Seasonal and spatial controls over nutrient cycling in a Pacific Northwest prairie, Ecosystems, 10, 1250-1260, doi:10.1007/s10021-007-9093-0.

Piao, S., P. Friedlingstein, P. Ciais, N. Noblet-Ducoudre, D. Labat, and S. Zaehle (2007), Changes in climate and land use have a larger direct impact than rising $\mathrm{CO}_{2}$ on global river runoff trends, Proc. Natl. Acad. Sci. U. S. A., 104(39), 15,242-15,247, doi:10.1073/pnas.0707213104.

Piechota, T., J. Timilsena, and G. Tootle (2004), The western U.S. drought: How bad is it?, Eos Trans. AGU, 85(32), 301, doi:10.1029/2004EO320001.

Raich, J. W., E. B. Rastetter, J. M. Melillo, D. W. Kicklighter, P. A. Steudler, B. J. Peterson, A. L. Grace, B. Moore Iii, and C. J. Vörösmarty (1991), Potential net primary productivity in South America: Application of a global model, Ecol. Appl., 1(4), 399-429, doi:10.2307/1941899.

Richards, J. H., and M. M. Caldwell (1987), Hydraulic lift: Substantial nocturnal water transport between soil layers by Artemisia tridentata roots, Oecologia, 73, 486-489, doi:10.1007/BF00379405.

Running, S. W. (2006), Is global warming causing more, larger wildfires?, Science, 313, 927-928, doi:10.1126/science.1130370.

Running, S. W., and R. R. Nemani (1991), Regional hydrologic and carbon balance responses of forests resulting from potential climate change, Clim. Change, 19, 349-368, doi:10.1007/BF00151173.

Rustad, L. E., J. L. Campbell, G. M. Marion, R. J. Norby, M. J. M. Itchell, A. E. Hartley, J. H. C. Cornelissen, and J. Gurevitch (2001), A metaanalysis of the response of soil respiration, net nitrogen mineralization, and aboveground plant growth to experimental ecosystem warming, Oecologia, 126, 543-562, doi:10.1007/s004420000544.

Scott, R. L., E. P. Hamerlynck, G. D. Jenerette, M. S. Moran, and G. A. Barron-Gafford (2010), Carbon dioxide exchange in a semidesert grassland through drought-induced vegetation change, J. Geophys. Res., 115 G03026, doi:10.1029/2010JG001348.

Seager, R., et al. (2007), Model projections of an imminent transition to a more arid climate in southwestern North America, Science, 316, 1181-1184, doi:10.1126/science. 1139601 .

Sheffield, J., and E. F. Wood (2008), Projected changes in drought occurrence under future global warming from multi-model, multi-scenario, IPCC AR4 simulations, Clim. Dyn., 31, 79-105, doi:10.1007/s00382007-0340-z.

Shuttleworth, W. J., and J. S. Wallace (1985), Evaporation from sparse crops: An energy combination theory, Q. J. R. Meteorol. Soc., 111 839-855, doi:10.1256/smsqj.46909.

Slack, J. R., A. M. Lumb, and J. M. Landwehr (1993), Hydro-Climatic Data Network (HCDN): Streamflow Data Set, 1874-1988, U.S. Geol Surv. Water Resour. Invest. Rep., 93-4076. (Available at http://pubs. usgs.gov/wri/wri934076/)

Sokolov, A. P., D. W. Kicklighter, J. M. Melillo, B. Felzer, C. A. Schlosser, and T. W. Cronin (2008), Consequences of considering carbon/nitrogen interactions on the feedbacks between climate and the terrestrial carbon cycle, J. Clim., 21, 3776-3796, doi:10.1175/2008JCLI2038.1.

Taylor, G. E., D. W. Johnson, and C. P. Andersen (1994), Air pollution and forest ecosystems: A regional to global perspective, Ecol. Appl., 4, 662-689, doi:10.2307/1941999.

Taylor, J. R. (1982), An introduction to error analysis, 270 pp., Univ. Sci. Books, Mill Valley, Calif.

Thomas, R. Q., C. D. Chanham, K. C. Weathers, and C. L. Goodale (2010), Increased tree carbon storage in response to nitrogen deposition in the U.S., Nat. Geosci., 3, 13-17, doi:10.1038/ngeo721.

Thornton, P. E., et al. (2002), Modeling and measuring the effects of disturbance history and climate on carbon and water budgets in evergreen needleleaf forests, Agric. For. Meteorol., 113, 185-222, doi:10.1016 S0168-1923(02)00108-9

Thornton, P. E., S. C. Doney, K. Lindsay, J. K. Moore, N. Mahowald, J. T. Randerson, I. Fung, J. F. Lamarque, J. J. Feddema, and Y. H. Lee (2009), Carbon-nitrogen interactions regulate climate-carbon cycle feedbacks: Results from an atmosphere-ocean general circulation model, Biogeosci. Discuss., 6, 3303-3354, doi:10.5194/bgd-6-3303-2009.

Tian, H., J. M. Melillo, D. W. Kicklighter, A. D. McGuire, and J. Helfrich (1999), The sensitivity of terrestrial carbon storage to historical climate variability and atmospheric $\mathrm{CO}_{2}$ in the United States, Tellus, Ser. B, 51, 414-452, doi:10.1034/j.1600-0889.1999.00021.x.

Unland, H. E., A. M. Arain, C. Harlow, P. R. Houser, J. Garatuza-Payan, P. Scott, O. L. Sen, and W. J. Shuttleworth (1998), Evaporation from a riparian system in a semi-arid environment, Hydrol. Processes, 12 , 527-542, doi:10.1002/(SICI)1099-1085(19980330)12:4<527::AIDHYP597>3.0.CO;2-R

van Mantgem, P. J., et al. (2009), Widespread increase of tree mortality rates in the western United States, Science, 323, 521-524, doi:10.1126/ science. 1165000

Vörösmarty, C. J., B. Moore III, and A. L. Grace (1989), Continental scale model of water balance and fluvial transport: An application to south America, Global Biogeochem. Cycles, 3, 241-265, doi:10.1029/ GB003i003p00241.

Vourlitis, G. L., G. Zorba, S. C. Pasuini, and R. Mustard (2007), Chronic nitrogen deposition enhances nitrogen mineralization potential of semiarid shrubland soils, Soil Sci. Soc. Am. J., 71, 836-842, doi:10.2136 sssaj2006.0339.

Westerling, A. L., H. G. Hidalgo, D. R. Cayan, and T. W. Swetnam (2006), Warming and earlier spring increase western U.S. forest wildfire activity, Science, 313, 940-943, doi:10.1126/science.1128834.

Wilcox, B. P., S. L. Dowhower, W. R. Teague, and T. L. Thurow (2006), Long-term water balance in a semiarid shrubland, Rangeland Ecol. Manage., 59, 600-606, doi:10.2111/06-014R3.1.

Wilcox, B. P., Y. Huang, and J. W. Walker (2008), Long-term trends in streamflow from semiarid rangelands: Uncovering drivers of change, Global Change Biol., 14, 1676-1689, doi:10.1111/j.1365-2486. 2008.01578.x.

Wilson, K., et al. (2002), Energy balance closure at FLUXNET sites, Agric. For. Meteorol., 113, 223-243, doi:10.1016/S0168-1923(02)00109-0.

$\mathrm{Xu}, \mathrm{L}$. , and D. D. Baldocchi (2004), Seasonal variation in carbon dioxide exchange over a Mediterranean annual grassland in California, Agric. For. Meteorol., 123, 79-96, doi:10.1016/j.agrformet.2003.10.004.

Zaehle, S., P. Friedlingstein, and A. D. Friend (2010), Terrestrial nitrogen feedbacks may accelerate future climate change, Geophys. Res. Lett., 37, L01401, doi:10.1029/2009GL041345.

Zhang, L., B. K. Wylie, L. Ji, T. G. Gilmanov, and L. L. Tieszen (2010), Climate-driven interannual variability in net ecosystem exchange in the northern Great Plains grasslands, Rangeland Ecol. Manage., 63(1), 40-50, doi: $10.2111 / 08-232.1$.

T. W. Cronin and C. A. Schlosser, MIT Joint Program on the Science and Policy of Global Change, Massachusetts Institute of Technology, 77 Massachusetts Ave., Cambridge, MA 02139, USA.

S. R. S. Dangal and B. S. Felzer, Earth and Environmental Sciences Department, Lehigh University, 1 W. Packer Ave., Bethlehem, PA 18015, USA.

D. W. Kicklighter and J. M. Melillo, Ecosystems Center, Marine Biological Laboratory, 7 MBL St., Woods Hole, MA 02543, USA. 